\title{
Modal Analysis of Rock Forming Minerals: Contribution of XRD/Rietveld Analysis Compared to the Classic Point Counting Method
}

\author{
Hamza Samouh $^{1 *}$, Shoji Nishimoto ${ }^{2}$, Hidekazu Yoshida ${ }^{3}$, Shohei Sawada ${ }^{4}$, Osamu Kontani ${ }^{5}$, \\ Kiyoteru Suzuki ${ }^{6}$ and Ippei Maruyama ${ }^{7^{*}, 8}$
}

\begin{abstract}
The determination of the mineral composition of aggregates which constitute an important component of concrete is essential to understand and estimate the durability of structures. The modal (quantitative mineralogical) analysis of rocks is generally determined by point-counting method on thin sections or slabs. However, there is a difficulty of mineral identification depending not only on the experience and capability of the operator but also on the size of observable grains In this study, XRD (X-Ray Diffraction)/Rietveld analysis is proposed as an alternative and a comparison study is performed for eight different rocks. The results show equivalent proportions to those of the point counting method for the major phases (minerals), although discrepancies are observed for the minor minerals. Complementary tests as XRF (X-Ray Fluorescence) and density measurements are also performed to pre-characterize and confirm the obtained modal analysis. For instance, the density calculations based on XRD/Rietveld analysis provide close values to the measured densities. Overall, this method can be an excellent alternative to the point counting method especially in the context of construction materials laboratory.
\end{abstract}

\section{Introduction}

After the implementation of restrictions for construction of new nuclear powerplants (NPP) around the world, the aging management of preexisting ones becomes more important. Indeed, the safety of these infrastructures is crucial to reach different national objectives, as meeting the growing energy needs or reducing the greenhouse emissions. As a result, different countries are extending the exploitation lifetime of their NPPs (Rosseel et al. 2016). Concrete based structures provide multiple functions for NPPs as foundation, support, shielding and containment (Naus 2012). These structures are generally

\footnotetext{
${ }^{1}$ Project appointed assistant professor, Department of Environmental Engineering and Architecture, Nagoya University, Furo-cho, Chikusa-ku, Nagoya, Japan. *Corresponding author, E-mail: samouh.hamza@g.mbox.nagoya-u.ac.jp

${ }^{2}$ Professor, Aichi University, Nagoya, Japan.

${ }^{3}$ Professor, Nagoya university museum, Nagoya, Japan.

${ }^{4}$ Group leader, Nuclear Power Department, Kajima corporation, Tokyo, Japan.

${ }^{5}$ Principal engineer, Nuclear Power Department, Kajima corporation, Tokyo, Japan.

${ }^{6}$ Senior researcher, Mitsubishi Research Institute, Inc., Tokyo, Japan.

${ }^{7}$ Professor, Department of Environmental Engineering and Architecture, Nagoya University, Nagoya, Japan.

*Corresponding author,

E-mail: i.maruyama@nagoya-u.jp

${ }^{8}$ Professor, Department of Architecture, The University of Tokyo, Tokyo, Japan.
}

not replaceable, and any degradation signifies a direct reduction of the service lifetime. Hence the importance of a better aging management through an accurate evaluation of the concrete behavior.

Radiation damage of concrete is reflected by the reduction of the engineering properties like strength and shielding capacity (Rosseel et al. 2016). For instance, under the combined effect of heat and radiation, modifications in concrete are observed for dimensions (generally expansion but shrinkage sometimes like for clay granulates), weight (due to the cement paste dehydration) and mechanical properties (Elleuch et al. 1972; Maruyama et al. 2017). The first order mechanism behind this reduction was determined as radiation-induced volumetric expansion (RIVE) of aggregates (Field et al. 2015; Hilsdorf et al. 1978; Maruyama et al. 2017). The amorphization (metamictization) of crystalline structures induced by radiations decreases the density of minerals and causes the RIVE. The expansion of aggregates creates a differential strain between cement paste and aggregates (Maruyama et al. 2016; Sasano et al. 2021). This strain is restrained creating stress and cracks through the concrete. A similar differential behavior exists also at the level of aggregates between the different composing minerals (Denisov et al. 2012; Maruyama et al. 2017; Le Pape et al. 2018). The RIVE is related to many properties of the original rock like its mineral composition, grain size and orientation of minerals (Denisov et al. 2012; Maruyama et al. 2017; Le Pape et al. 2020). For instance, it is well known that silicate-bearing aggregates develop higher RIVE compared to carbonate-bearing aggregates (Maruyama and Muto 2016; Le Pape et al. 2018). Therefore, to assess the degradation risk of the biological shield, it is neces- 
sary to have the accurate mineralogy of aggregates and their properties in a such environment (Maruyama et al. 2017; Le Pape et al. 2020).

Extensive experimental and theoretical studies have been performed for some common minerals under radiation like silica, alumina and zircon (Ewing 1994). This is clearly the example of quartz thanks to its various application as glasses for optical devices, electronic components or as a part of natural aggregates for construction materials. Inside nuclear reactor, quartz alters gradually, and its properties vary consequently by a decrease in density, disappearance of the alpha-beta transition and changes in the absorption spectrum. (Bolse 1999). The irradiated quartz defined mineralogically as metamict (Pabst 1952), is somewhat different from ordinary vitreous silica with slightly higher density (Hobbs and Pascucci 1980) and corresponds to the single structural relaxation product of highly defective matrix (Douillard and Duraud 1996). quartz amorphizes easily at very low fluences due to its exactly constrained structure and its expansion can be explained one part by the structure wakening due to the breaking of bounds, and another part by the new emplacements of the atoms in a tighter part of the structure (Primak et al. 1955). There are also different parameters which influences the expansion of the irradiated quartz as temperature (Bykov et al. 1981; Luu et al. 2020) or the nature of the irradiating particles (Douillard and Duraud 1996). However, similar knowledge is very hard to find for all the minerals composing aggregates used in the NPPs, despite its importance for studying the radiation-damage in order to attenuate radiation or immobilize the radioactive waste (Ewing et al. 1987).

To remedy this situation, it is necessary first to develop easy way for identifying the different minerals composing aggregates. This paper aims to compare two methods for modal (quantitative mineralogical) analysis of rocks. The first one is the classic point counting method on thin section and the second one is an approach based on the XRD (X-Ray Diffraction)/Rietveld analysis. Both methods present different advantages and disadvantages that making them suitable in different cases according to the available resources and targeted objectives.

The point counting method is a proven method with recognized accuracy for the identification and quantification of minerals (Poole and Sims 2016). It is a suitable technique for samples without any prior information or pre-characterization. However, it is a time-consuming for the sample preparation and its analysis (this last step can be reduced by using the digital imaging analysis) (Livingood and Cordell 2009). This method is unable to identify accurately the minerals from the same group as plagioclase, alkali-feldspars and clay minerals (Ufer et al. 2008). It is also difficult to distinguish minerals with similar optic properties like opaque minerals (magnetite, ilmenite, hematite, pyrite, pyrrhotite, graphite, etc.). The identification is also restricted by the observable size of grains by microscope. The obtained result presents generally a high standard deviation, and it is directly affected by the human errors committed during the counting process.

The XRD analysis is time saver and simple to use compared to traditional methods (Ovas and Uda 2004; Bish and Post 1993). Also, for a laboratory of cementitious materials, the XRD equipment becomes more and more common with a noticeable growing experience and proficiency of the users. Indeed, many applications of the XRD/Rietveld analysis can be found in literature not only in the geological field but also in the applied engineering field like construction materials. Thus, XRD/Rietveld analysis is a powerful tool to obtain information related to cement hydration (Scrivener et al. 2016), to alkali-silica reaction in concrete (Marinoni and Broekmans 2013) or to link the drying shrinkage of concrete to the clay minerals content of aggregates (Igarashi et al. 2015). With accurate identification of minerals, a successful quantification based on XRD methods is possible (Omotoso et al. 2006). It also provides indicative data about the amorphous content (Philippo et al. 1997), but special attention should be given to the powder preparation since an extensive grinding can lead to amorphization (O'Connor and Chang 1986). It can be used to determine the mineral composition (Alves et al. 2007; Brinatti et al. 2010), but for more complete characterization it is preferable to perform chemical analysis which is complementary to XRD especially in case of high amorphous content (Jercher et al. 1998). The Rietveld analysis requires structure model of the composing minerals (Kaufhold et al. 2012), but it is generally inappropriate to describe minerals with stacking faults like clays as ideal crystallites (Ufer et al. 2008; Omotoso et al. 2006). Also, some problems of XRD quantification can be linked for example to the platy habit and cleavability of some minerals with unknown degrees of preferred orientation (Kleeberg et al. 2008). The analyst experience is very important for a successful quantification for which the average bias is around $10 \%$ to $15 \%$ (Omotoso et al. 2006).

The quantitative phase analysis can also be performed based on the element composition, but it is difficult in case of complex assemblage of minerals and the uniqueness of the solution is not guaranteed (Herrmann and Berry 2002). Therefore, it is preferable to use the elemental analysis as pre-characterization test (Omotoso et al. 2006). An idealized mineral composition can be obtained by the CIPW (Cross, Iddings, Pirsson and Washington) normative calculation (Cross et al. 1902).

The density measurements of the studied rocks will be used as a confirmation test. It will allow the comparison between the measured density and the density calculated from the mineral composition obtained by XRD/Rietveld analysis.

In summary, The XRF (X-Ray Fluorescence) and CIPW norm will provide respectively the oxide composition 
and an ideal phase composition as pre-characterization step before the XRD/Rietveld analysis. The results obtained by this approach will be compared to those of the point counting method for eight different rocks. The measured density will be used as a confirmation test for the obtained phase quantification.

\section{Experiment}

In this paper, two methods for the identification and quantification of phases inside rock-forming minerals are presented and compared. The first one is the classic point counting method operated on the thin sections prepared from the studied rocks. The second one is an approach combining the XRF, XRD/Rietveld analysis. The main minerals in the earth's crust are: plagioclase (39\%), k-feldspar (12\%), quartz (12\%), pyroxenes (11\%), micas $(5 \%)$, clays $(5 \%)$, other silicates $(5 \%)$ and non-silicates (8\%) (Ronov and Yaroshevsky 1966). Knowing that, the XRF provides the oxides in the rock allowing to have an idea about the phases inside the studied rock by calculating the CIPW norm. The crystal structures corresponding to these phases are used for the Rietveld analysis. Thus, the phases inside the rocks can be correctly identified and quantified. To confirm the obtained results, density measurements are performed by the Helium Pycnometer. By using equation (1), the density can be estimated based on the proportions of minerals given by the XRD/Rietveld analysis. The comparison of both values, measured and calculated, can confirm or not the exactitude of our identification/quantification of phases. The details about the different tests are described in the following sections.

$$
\rho=\frac{\sum_{i=0}^{n} m_{i}}{\sum_{i=0}^{n} V_{i}}=1 / \sum_{i=0}^{n} \frac{1}{\rho_{i}} \frac{m_{i}}{\sum_{j=0}^{n} m_{j}}
$$

where $i$ and $j$ are dumb variables. $n$ number of phases in the rock. $\rho$ density of the rock. $\rho_{i}$ density of the phase $i$. $m_{i}$ and $\mathrm{m}_{\mathrm{j}}$ masses of the phases $i$ and $j$.

\subsection{Materials}

To compare the point counting method with the XRD/Rietveld analysis, eight rocks have been collected. Since feldspars are very common as rock forming minerals, one plagioclase (albitite) and one k-feldspar (pegmatite) have been chosen for this study to be representative of this group. The quartz mineral is also very common in natural aggregates, and to consider this kind of rocks, the metachert will be studied. In the context of nuclear concrete, it is very interesting to study a rock incorporating different minerals which can provide an important insight concerning the internal differential behavior for the same aggregate. Thus, granite which is roughly constituted from quartz, feldspars and mica has been selected. Also, the basalt is a very common rock with different minerals, but since it is a mafic extrusive, it develops smaller crystals. This difference between granite and basalt will allow to observe the effect of the grain size. For this project, it was also requested to work with natural rock with non-negligible fraction of glassy phases. Therefore, andesite rock was a good candidate to satisfy this point. It is also important to consider sedimentary rocks like the chosen sandstone. Finally, the heavy rocks are generally preferred for nuclear infrastructures since they offer a higher coefficient of attenuation for radiation. Peridotite is one of these rocks and will be studied in this perspective. The list of different rocks with their origins are as follows:

1. Albitite from Itoigawa city, Niigata prefecture, Japan.

2. Pegmatite from India.

3. Granite from Takamatsu city, Kagawa prefecture, Japan.

4. Metachert from Kasugai city, Aichi prefecture, Japan.

5. Basalt from Karatsu city, Saga prefecture, Japan.

6. Andesite from Satsumasendai city, Kagoshima prefecture, Japan.

7. Sandstone from Tsuruga city, Fukui prefecture, Japan.

8. Peridotite, from Samani district in Hidaka subprefecture, Hokkaido, Japan.

Pieces of rocks have been extracted from the surface without any observable macro-defects. From these pieces, the samples used for the tests were prepared as follows:

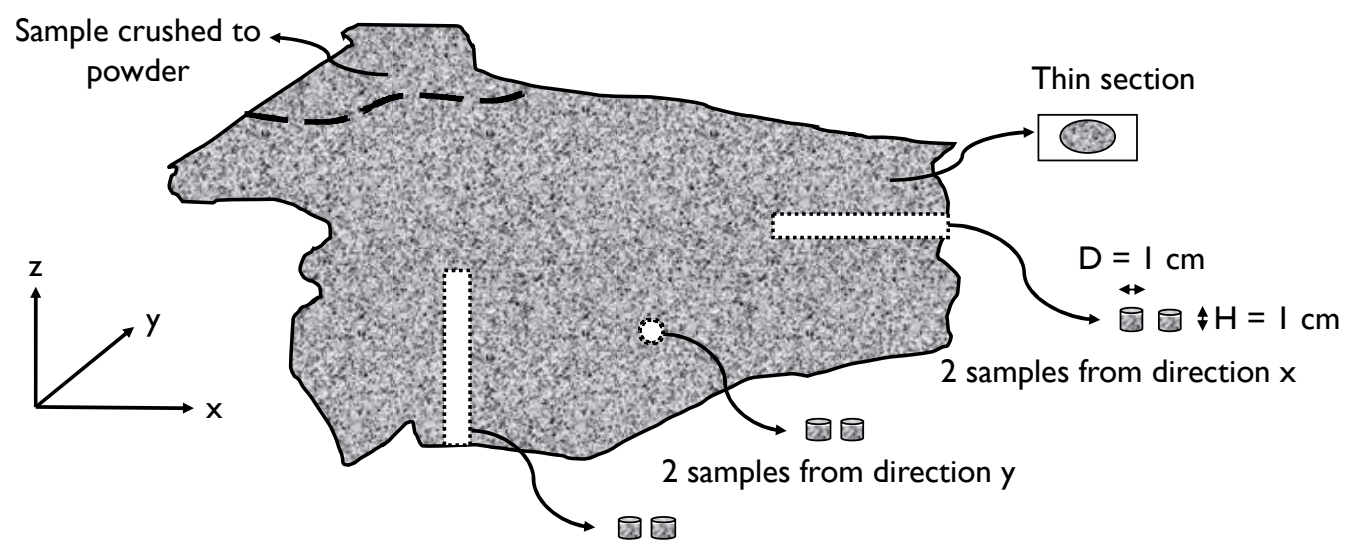

2 samples from direction $\mathbf{z}$

Fig. 1 Extraction of samples and powder from the original rock. 
1. Powder for the XRF and XRD measurements.

2. Thin section for the point counting method.

3. For the Helium density measurements, six cylindrical samples were cored. Two from each direction: $\mathrm{x}, \mathrm{y}$ and $\mathrm{z}$ as indicated in Fig. 1. Their dimensions are $1 \mathrm{~cm}$ of diameter and $1 \mathrm{~cm}$ of height.

A small part of the rock (around $20 \mathrm{~g}$ ) was wet-cut, and it was wiped then conserved in controlled temperature room $\left(20^{\circ} \mathrm{C}\right)$ to dry for at least one day. After this it was crushed to make the necessary powder for the XRD and XRF measurements. This piece of the rock was grinded up to $2 \mathrm{~min}$ (with cycles of $30 \mathrm{~s}$ ) and only the powder inferior to $90 \mu \mathrm{m}$ has been conserved for the tests. In general, the fraction of the particles meeting this condition represents more than $90 \%$ of the total obtained powder.

More details concerning the preparation of the samples and the measurements are presented in the following sections.

\subsection{Modal analysis}

\section{(1) X-ray fluorescence (XRF)/ CIPW norm}

The prepared powder was used to measure the composition of oxides by XRF according to the JIS R 5204 . Measurements were performed with a glass bead using a wavelength dispersion- type fluorescent X-ray analyzer. The Axios mAX from Malvern Panalytical was used for this characterization. The obtained bulk chemical composition was used to determine the idealized mineralogy by the CIPW norm method (Cross et al. 1902). A free access Excel spreadsheet program was used for this calculation (Hollocher 2009) and the same reference provides an extensive explanation for the CIPW method.

\section{(2) Polarized micrograph and point counting method}

From the original sample, a small piece of the rock was cut with two parallel surfaces. One surface of this piece was polished before been glued to a rectangular glass. The used thermic glue and glass are designed for the petrographic observation by polarization microscopy. The obtained glued sample in the glass was then cut again to obtain a very thin section. This remaining piece of the glued rock was polished gently until reaching 30 $\mu \mathrm{m}$ of the section thickness (CEN-EN 12407 2019). For this thickness, the minerals can be distinguished and studied by a polarized microscope because the most of them become transparent. The micrograph images were obtained under PPL (plane polarized light) and XPL (cross polarized light) to determine the minerals existing in the studied rocks. Thanks to a mechanical stage, the modal analysis is performed in grid intersection with a constant distance between two successive points. Depending on the different visual properties (like twining for plagioclase) exhibited under PPL and/or XPL, each selected point is affected to the identified corresponding mineral.

The relative percentage of a given mineral is calcu- lated as the ratio between the number of points corresponding to this mineral and the total number of points. According to the grain size of phases in the thin section, the total number of studied points should be chosen (Larrea et al. n.d.). For this study, 1000 points were chosen for the count in the thin section with a pitch of 0.5 $\mathrm{mm}$ which correspond to an area around $2.23 \mathrm{~cm}^{2}$. The value of this pitch is chosen to consider the largest possible area of the rock, increasing the number of targeted grains, and enhancing the representativity of the sampling. Similar values can be found in literature for thin section of the rocks (Byers et al. 1990).

\section{(3) X-ray diffraction (XRD) / Rietveld analysis}

For each studied rock, a part of the obtained powder was mixed with the pure corundum $\left(\alpha-\mathrm{Al}_{2} \mathrm{O}_{3}\right)$ with $90 \%$ and $10 \%$ of mass ratio, respectively. The D8 Advance XRD instrument (Bruker AXS, Karlsruhe, Germany) was used. The X-ray source was $\mathrm{CuK} \alpha$, with the tube voltage of 40 $\mathrm{kV}$ and tube current of $40 \mathrm{~mA}$. The scan field of $5^{\circ}<2 \theta<$ $70^{\circ}$ was used with a step size of $0.02^{\circ}$, and $0.65 \mathrm{~s} / \mathrm{step}$. The total time of each test was equal to $37 \mathrm{~min}$. The XRD measurements were done on three samples of $1 \mathrm{~g}$ of the mixed powder taken from the same prepared batch. In order to reduce the weighting error, $0.4 \mathrm{~g}$ of corundum is mixed with $3.6 \mathrm{~g}$ of the rock powder (Kaufhold et al. 2012).

The Rietveld analysis was performed with the software application TOPAS ver. 4.2 developed by Bruker AXS. The particle size and lattice parameters were optimized. The preferred crystal orientation was avoided to eliminate its negative effect on the reproducibility of refinement (Snellings et al. 2010). The starting point of the pure minerals used for the Rietveld analysis is $2 \theta=2^{\circ}$. If this low range does not exist in the used file, it is considered null. The results will be presented in this paper as the average and the standard deviation of the three tested samples. As indicators for the quality of the Rietveld analysis three parameters of the calculation will be given: $\mathrm{R}_{\mathrm{wp}}$ which is the weighted profile $\mathrm{R}$-factor, $\mathrm{R}_{\text {exp }}$ represents the expected R-factor which corresponds to the best possible $\mathrm{R}_{\mathrm{wp}}$. In addition to the GoF (Goodness of fit) defined as the ratio of $\mathrm{R}_{\mathrm{wp}}$ to $\mathrm{R}_{\exp }$ (Toby 2006). Concerning the crystal files of minerals, many references can be found like for the most common: albite (Harlow 1982), orthoclase (Vrsweueruanhnowic and Kielhorn 1983), microcline (Bailey 1969), quartz (Levien et al. 1980), biotite (Hendricks and Jefferson 1939). For similar information and structural files, the readers can use the American mineralogist crystal structure database (Downs and Hall-Wallace 2003) or to the crystallography open database (Downs et al. 2003: Gražulis et al. 2009, 2012, 2015; Merkys et al. 2016; Quirós et al. 2018; Vaitkus et al. 2021).

\section{(4) Density by Helium pycnometer}

For each studied rock, the density was assessed by Helium pycnometer Ultrapyc 1200e of Quantachrome In- 
Table 1 Bulk composition of the studied rocks by X-ray fluorescence (XRF) analysis.

\begin{tabular}{|c|c|c|c|c|c|c|c|c|}
\hline$(\mathrm{Wt} \%)$ & Albitite & Pegmatite & Granite & Metachert & Basalt & Sandstone & Peridotite & Andesite \\
\hline $\mathrm{Ig.loss}$ & 0.42 & 0.11 & 0.21 & 0.52 & 1.23 & 1.51 & 2.61 & 1.40 \\
\hline $\mathrm{Na}_{2} \mathrm{O}$ & 12.18 & 1.86 & 3.94 & 0.24 & 3.10 & 4.58 & - & 2.94 \\
\hline $\mathrm{MgO}$ & 0.15 & - & 0.22 & 0.46 & 7.24 & 1.00 & 46.14 & 4.02 \\
\hline $\mathrm{Al}_{2} \mathrm{O}_{3}$ & 20.75 & 20.04 & 15.18 & 2.23 & 14.13 & 14.41 & 0.59 & 15.95 \\
\hline $\mathrm{SiO}_{2}$ & 64.24 & 65.55 & 72.20 & 94.32 & 41.79 & 69.84 & 40.50 & 58.20 \\
\hline $\mathrm{P}_{2} \mathrm{O}_{5}$ & - & 0.02 & 0.07 & 0.02 & 0.41 & 0.08 & - & 0.14 \\
\hline $\mathrm{SO}_{3}$ & 0.02 & 0.02 & 0.03 & - & - & 0.25 & 0.03 & 0.03 \\
\hline $\mathrm{Cl}$ & 0.05 & - & 0.08 & - & 0.09 & - & - & 0.14 \\
\hline $\mathrm{K}_{2} \mathrm{O}$ & 0.56 & 11.84 & 3.47 & 0.63 & 1.09 & 2.57 & - & 1.84 \\
\hline $\mathrm{CaO}$ & 0.97 & 0.13 & 2.07 & 0.27 & 8.39 & 1.30 & 0.24 & 6.94 \\
\hline $\mathrm{TiO}_{2}$ & - & - & 0.15 & 0.07 & 1.73 & 0.35 & - & 0.76 \\
\hline $\mathrm{Cr}_{2} \mathrm{O}_{3}$ & 0.06 & - & 0.07 & - & 0.07 & 0.14 & 0.43 & - \\
\hline $\mathrm{MnO}$ & - & - & 0.05 & 0.06 & 0.14 & 3.20 & 0.14 & 0.12 \\
\hline $\mathrm{Fe} \mathrm{O}_{3}$ & 0.32 & 0.28 & 2.21 & 1.09 & 10.25 & - & 8.73 & 7.00 \\
\hline $\mathrm{Co}_{3} \mathrm{O}_{4}$ & - & - & - & - & 9.83 & - & - & - \\
\hline $\mathrm{CuO}$ & - & - & - & - & - & - & - & - \\
\hline $\mathrm{ZnO}$ & - & - & 0.01 & - & 0.01 & 0.02 & - & - \\
\hline $\mathrm{Rb} \mathrm{D}_{2} \mathrm{O}$ & - & 0.04 & 0.01 & - & - & 0.01 & - & - \\
\hline $\mathrm{NiO}$ & - & - & - & - & - & - & 0.36 & 0.04 \\
\hline $\mathrm{SrO}$ & 0.08 & 0.02 & 0.02 & - & 0.06 & 0.04 & - & 0.05 \\
\hline $\mathrm{ZrO}$ & - & - & - & - & 0.08 & - & - & - \\
\hline $\mathrm{BaO}$ & 0.07 & - & - & - & - & 0.24 & - & - \\
\hline $\mathrm{PbO}$ & - & 0.03 & - & - & - & - & - & - \\
\hline $\mathrm{I}$ & 0.14 & 0.07 & - & - & 0.35 & 0.47 & 0.22 & 0.41 \\
\hline $\mathrm{Total}$ & 99.99 & 100.00 & 100.00 & 99.91 & 100.00 & 100.00 & 100.00 & 100.00 \\
\hline
\end{tabular}

struments. The six cylindrical samples obtained for each rock were used for this test. The volume of the sample is measured up to 10 times until the standard deviation becomes less than $0.05 \%$. By measuring the mass of the sample, the density can be deduced with high accuracy. For a given rock, the result will be presented as the average and standard deviation of the six samples.

\section{Experimental results}

\subsection{XRF}

The X-Ray fluorescence (XRF) results for the chosen rocks are presented in the Table 1. The oxide composition was implemented in the Excel spreadsheet program to obtain the CIPW norm. The presentation of these results and their discussion will be done for each rock in the following sections.

\subsection{Albitite}

The chemical composition obtained by XRF is presented in Table 1. More than $97 \%$ of the rock are formed by $\mathrm{SiO}_{2}, \mathrm{Al}_{2} \mathrm{O}_{3}$ and $\mathrm{Na}_{2} \mathrm{O}$ while $\mathrm{K}_{2} \mathrm{O}$ and $\mathrm{CaO}$ are under $2 \%$. These proportions are related to the presence of albite as shown by the CIPW results presented in Table 2.

The photomicrographs of albitite under PPL and XPL are presented in Figs. 2(a) and (b). The twining of plagioclase (albite) can be observed in addition to some quartz grains. The grain size of these minerals (phases) is in the order of $1 \mathrm{~mm}$. The estimated mineral composition by the point counting method is presented in Table 2 . The result of the point counting method shows that this rock is mainly composed of plagioclase with low per- centage of quartz and calcite with some minor unidentified phases $(0.4 \%)$.

The experimental XRD curve with the identification of phases are presented in Fig. 2(c). This experimental curve was well reproduced and the parameters showing that are: $R_{\exp }=2.52, R_{w p}=13.41$ and $G o F=5.31$. In addition to albite and quartz, many other phases have been tested then excluded except calcite for which a small content has been detected. The final composition of this last method is also presented in Table 2. Globally, similar result with high plagioclase content is found, especially with CIPW results (on powder obtained from the same batch) for which a similar percentage of albite is obtained. Like the CIPW calculation but unlike the point-counting method, no quartz has been observed by XRD/Rietveld method. Also, the percentage of calcite is lower for the XRD/Rietveld analysis compared to the point-counting method. This difference is due to the natural heterogeneity of the rock reflected in the different sampling. The Rietveild analysis presents non negligible amount of amorphous $(17 \%)$ which has not been observed by microscopy. This value can be explained by the artefact linked to the approach.

The density estimation based on the identified crystal phases gives approximately the same value as that measured by the Helium pycnometer. The difference is around $0.54 \%$ between the calculated density equal to 2.620 and the experimental density equal to $2.606 \pm$ 0.010 . This result presents an additional confirmation for the phase quantification obtained by the XRD/Rietveld analysis. 
Table 2 Phase composition of albitite given by point-counting on thin section and XRD/Rietveld analysis.

\begin{tabular}{|c|c|c|c|c|c|c|c|}
\hline \multicolumn{2}{|c|}{} & \multicolumn{2}{c|}{ CIPW } & \multicolumn{2}{c|}{ Thin section } & \multicolumn{2}{c|}{ XRD/Rietveld } \\
\hline Phase & Chemical formula & Density & $\begin{array}{c}\mathrm{Wt} \\
(\%)\end{array}$ & $\begin{array}{c}\text { Count } \\
(\%)\end{array}$ & $\begin{array}{c}\mathrm{SD} \\
(\%)\end{array}$ & $\begin{array}{c}\text { Wt } \\
(\%)\end{array}$ & $\begin{array}{c}\text { SD } \\
(\%)\end{array}$ \\
\hline $\begin{array}{c}\text { Plagioclase: } \\
\text { Albite }\end{array}$ & $\mathrm{NaAlSi}_{3} \mathrm{O}_{8}$ & 2.62 & 81.59 & 89.4 & 2.0 & 82.91 & 0.82 \\
\hline Quartz & $\mathrm{SiO}_{2}$ & 2.65 & - & 7.2 & 2.7 & - & - \\
\hline Calcite & $\mathrm{CaCO}_{3}$ & 2.71 & - & 3.0 & 1.5 & 0.26 & 0.02 \\
\hline Other & - & - & 17.59 & 0.4 & 0.8 & - & - \\
\hline Amorphous & - & - & - & - & - & 16.84 & 0.82 \\
\hline Total & & & 99.18 & 100 & & 100 & \\
\hline
\end{tabular}

\subsection{Pegmatite}

The chemical composition obtained by XRF is presented in Table 1. More than $97 \%$ of the rock are formed by $\mathrm{SiO}_{2}, \mathrm{Al}_{2} \mathrm{O}_{3}$ and $\mathrm{K}_{2} \mathrm{O}$ while $\mathrm{Na}_{2} \mathrm{O}$ and $\mathrm{CaO}$ are under $2 \%$. The CIPW results are presented in Table 3 and show the dominance of orthoclase/microcline (this method is unable to distinguish polymorphs), in addition to the presence of albite and quartz.

The thin section of the pegmatite rock under the PPL and XPL is presented in Figs. 3(a) and (b). The material seems to be composed by uniform dispersed feldspar with some inclusions like quartz and white mica. The order of the size of these inclusions is around $100 \mu \mathrm{m}$. The composition of this rock obtained by the point counting method is shown in Table 3 . The feldspars identified as microcline and albite constitute most minerals inside this rock.

The crystal structures of common minerals in pegmatite have been implemented for the Rietveld analysis. For this method, no trace of orthoclase was found but a small quantity of albite was detected. The XRD pattern is presented in Fig. 3(c) with the assignments of peaks. The reproduction of the experimental XRD pattern by the fitted one was done with the following parameters: $\mathrm{R}_{\exp }=2.78, \mathrm{R}_{\mathrm{wp}}=10.41$ and $\mathrm{GoF}=3.75$. The predominant minerals are detected by the three methods as shown in Table 3. The mica as a clay mineral is not included in the CIPW calculation. It was identified as lepidolite by the

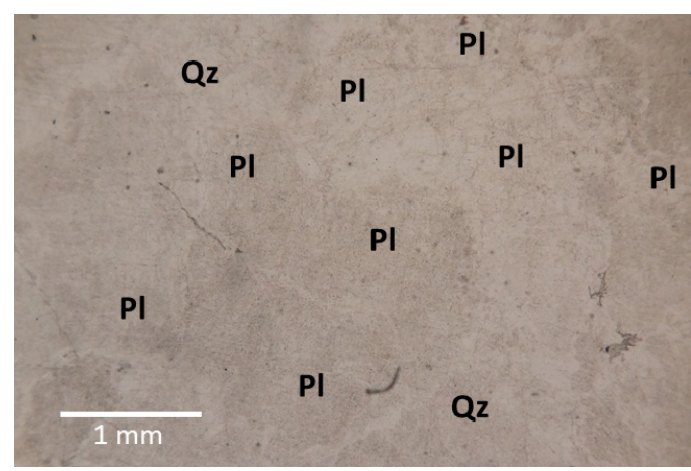

(a)

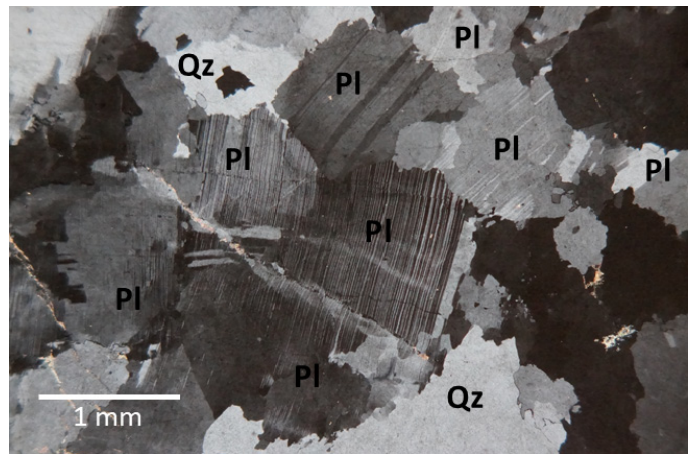

(b)

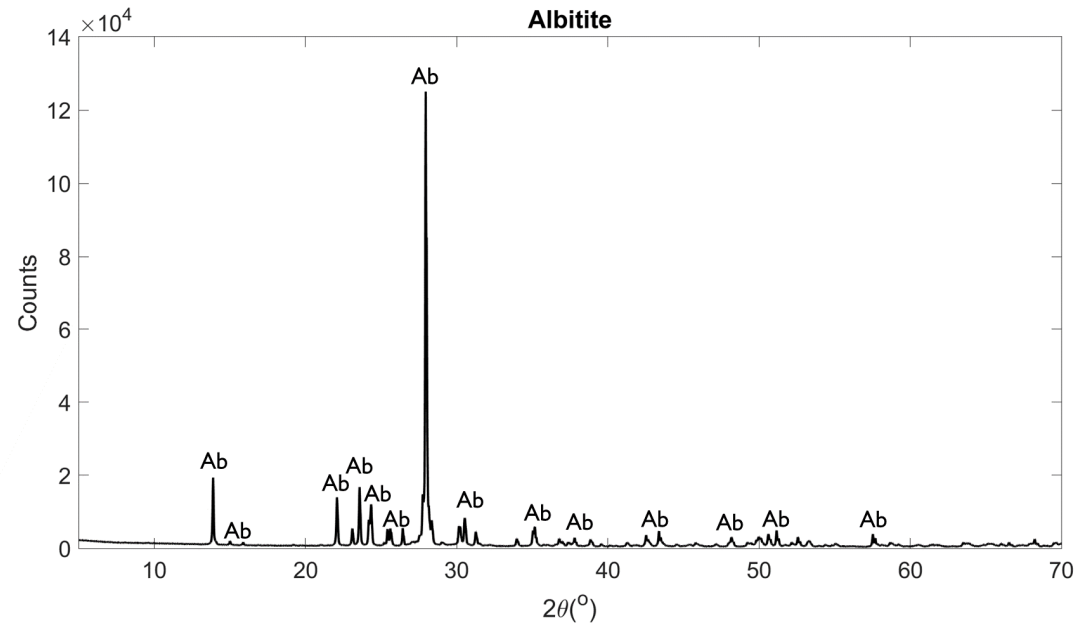

(c)

Fig. 2 (a) Micrograph under PPL for albitite thin section, (abbreviations: Qz for quartz and PI for plagioclase), (b) Micrograph under XPL for albitite thin section, (c) Experimental and fitted X-Ray diffraction pattern for the albitite with the dominant phase (abbreviations: Ab for albite). 
Table 3 Phase composition of pegmatite given by point-counting on thin section and XRD/Rietveld analysis.

\begin{tabular}{|c|c|c|c|c|c|c|c|}
\hline \multicolumn{2}{|c|}{} & \multicolumn{2}{c|}{ CIPW } & \multicolumn{2}{c|}{ Thin section } & \multicolumn{2}{|c|}{ XRD/Rietveld } \\
\hline Phase & Chemical formula & Density & $\begin{array}{c}\text { Wt } \\
(\%)\end{array}$ & $\begin{array}{c}\text { Count } \\
(\%)\end{array}$ & $\begin{array}{c}\text { SD } \\
(\%)\end{array}$ & $\begin{array}{c}\text { Wt } \\
(\%)\end{array}$ & $\begin{array}{c}\text { SD } \\
(\%)\end{array}$ \\
\hline Microcline & $\mathrm{KAlSi}_{3} \mathrm{O}_{8}$ & 2.56 & 69.97 & 74.0 & 3.6 & 79.36 & 0.44 \\
\hline Albite & $\mathrm{NaAlSi}_{3} \mathrm{O}_{8}$ & 2.62 & 16.12 & 20.2 & 3.4 & 8.04 & 0.54 \\
\hline Quartz & $\mathrm{SiO}_{2}$ & 2.65 & 9.09 & 4.0 & 1.9 & 1.55 & 0.21 \\
\hline White mica: lepidolite & $\mathrm{K}(\mathrm{Li}, \mathrm{Al})_{3}\left(\mathrm{Si}_{2}, \mathrm{Al}_{4} \mathrm{O}_{10}(\mathrm{~F}, \mathrm{OH})_{2}\right.$ & 2.84 & - & 1.8 & 1.4 & 0.66 & 0.13 \\
\hline Other & - & - & 4.54 & & & & \\
\hline Amorphous & - & - & - & - & - & 10.39 & 1.12 \\
\hline Total & & & 99.72 & 100 & & 100 & \\
\hline
\end{tabular}

$\mathrm{XRD} /$ Rietveild analysis which is impossible by both initial methods. As for the previous rock, the amorphous phase (around 10\%) was only detected by the XRD method. The thin section gives a higher percentage of albite, quartz, and white mica while microcline is slightly lower by this method.

The measured density for this rock is equal to $2.569 \pm$ 0.100 . The calculated density based on the phase quantification determined by the XRD/Rietveld analysis also gives the same value of 2.569 . It can be considered as a complementary confirmation of the obtained mass ratio of minerals obtained by this method.

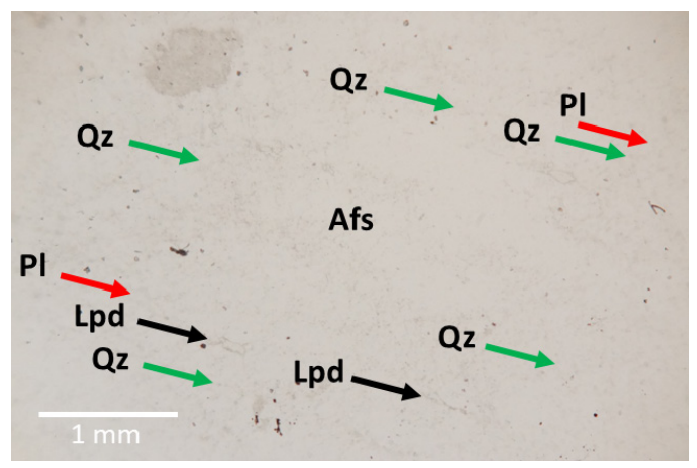

(a)

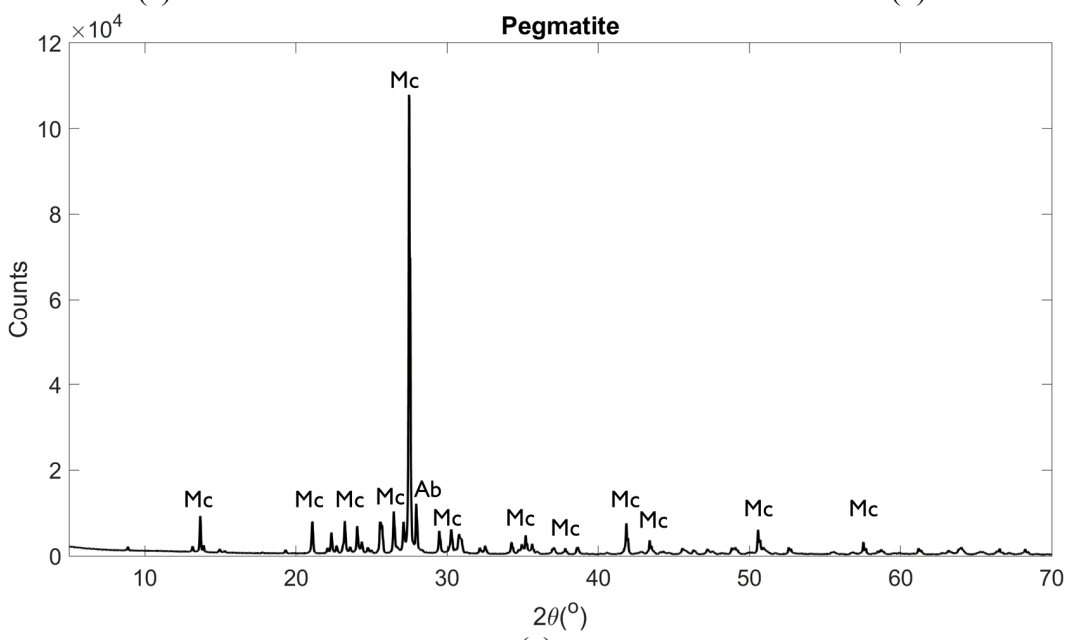

(c)

Fig. 3 (a) Micrograph under PPL for pegmatite thin section, (abbreviations: Qz for quartz, PI for plagioclase and Lpd for lepidolite -white mica-), (b) Micrograph under XPL for pegmatite thin section, (c) Experimental and fitted X-Ray diffraction pattern for the pegmatite with the dominant phase (abbreviations: Mc for microcline and Ab for albite).

\subsection{Granite}

The Oxides content in the granite rock is given by XRF test presented in Table 1 Bulk composition of the studied rocks by X-ray fluorescence (XRF) analysis. Based on the CIPW results presented in the Table 4, the dominant phases are consecutively albite, quartz, and k-feldspar while the hydrated minerals are not considered by this method.

The thin section of granite under PPL and XPL is presented in the Figs. 4(a) and (b). The size of quartz grains is in the order of $1 \mathrm{~mm}$. The biotite inclusions are in the order of $500 \mu \mathrm{m}$. Some alteration of biotite to chlorite can also be observed. The size order of this

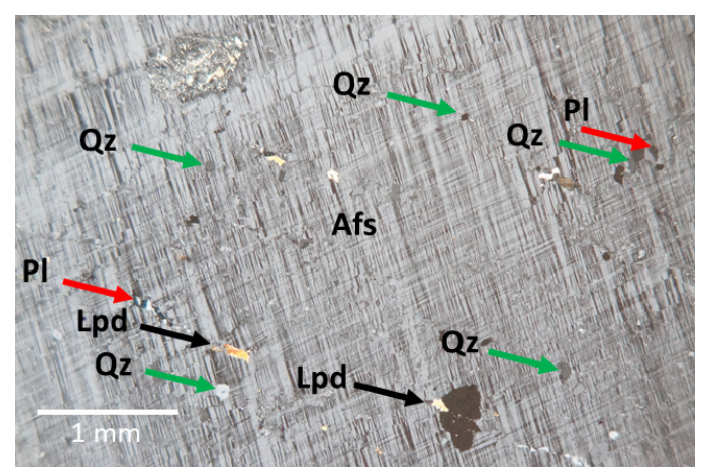

(b) 
Table 4 Phase composition of granite given by point-counting on thin section and XRD/Rietveld analysis.

\begin{tabular}{|c|c|c|c|c|c|c|c|}
\hline \multirow[b]{2}{*}{ Phase } & \multirow[b]{2}{*}{ Chemical formula } & \multirow[b]{2}{*}{ Density } & \multirow{2}{*}{$\begin{array}{c}\text { CIPW } \\
\text { Wt } \\
(\%)\end{array}$} & \multicolumn{2}{|c|}{ Thin section } & \multicolumn{2}{|c|}{ XRD/Rietveld } \\
\hline & & & & $\begin{array}{l}\text { Count } \\
(\%)\end{array}$ & $\begin{array}{l}\mathrm{SD} \\
(\%)\end{array}$ & $\begin{array}{l}\mathrm{Wt} \\
(\%)\end{array}$ & $\begin{array}{l}\text { SD } \\
(\%)\end{array}$ \\
\hline Quartz & $\mathrm{SiO}_{2}$ & 2.65 & 31.02 & 34.4 & 6.7 & 33.43 & 0.60 \\
\hline $\begin{array}{l}\text { Plagioclase: } \\
\text { Albite }\end{array}$ & $\mathrm{NaAlSi}_{3} \mathrm{O}_{8}$ & 2.62 & 41.62 & 31.0 & 6.8 & 31.60 & 0.86 \\
\hline $\begin{array}{l}\text { K-feldspar: } \\
\text { Orthoclase } \\
\text { Microcline }\end{array}$ & $\mathrm{KAlSi}_{3} \mathrm{O}_{8}$ & 2.56 & 20.51 & 23.4 & 12.6 & $\begin{array}{c}21.08= \\
10.73+ \\
10.35\end{array}$ & $\begin{array}{c}2.25= \\
0.62+ \\
1.62\end{array}$ \\
\hline Biotite & $\mathrm{K}(\mathrm{Mg}, \mathrm{Fe})_{3}(\mathrm{OH}, \mathrm{F})_{2}\left(\mathrm{Si}_{3} \mathrm{AlO}_{10}\right)$ & 3.09 & - & 8.4 & 3.0 & 3.21 & 0.34 \\
\hline Amphibole & $\{\mathrm{Na}\}\left\{\mathrm{Ca}_{2}\right\}\left\{\mathrm{Mg}_{4} \mathrm{Al}\right\}\left(\mathrm{Al}_{2} \mathrm{Si}_{6} \mathrm{O}_{22}\right)(\mathrm{OH})_{2}$ & 3.12 & - & 1.3 & 0.8 & 0.97 & 0.03 \\
\hline Fluorite & $\mathrm{CaF}_{2}$ & 3.13 & - & 0.8 & 1.0 & 0.11 & 0.03 \\
\hline $\begin{array}{l}\text { Muscovite and } \\
\text { opaque minerals }\end{array}$ & $\mathrm{KAl}_{2}\left(\mathrm{AlSi}_{3} \mathrm{O}_{10}\right)(\mathrm{OH}, \mathrm{F})_{2}$ & 2.82 & - & 0.3 & 0.5 & 2.06 & 0.35 \\
\hline Chlorite & $(\mathrm{Fe}, \mathrm{Mg}, \mathrm{Al})_{6}(\mathrm{Si}, \mathrm{Al})_{4} \mathrm{O}_{10}(\mathrm{OH})_{8}$ & 2.95 & - & 0.2 & 0.4 & 0.52 & 0.07 \\
\hline Zircon & $\mathrm{ZrSiO}_{4}$ & 4.65 & - & 0.2 & 0.4 & 0.13 & 0.02 \\
\hline Other & - & - & 6.24 & - & - & - & - \\
\hline Amorphous & - & - & - & - & - & 3.93 & 2.35 \\
\hline Total & & & 99.39 & 100 & & 100 & \\
\hline
\end{tabular}

chlorite is under $160 \mu \mathrm{m}$. The phase quantification given by the point counting method is presented in Table 4 . The same predominant phases are also obtained by this test. biotite exists with a non-negligible percentage with some other minor phases: amphibole, fluorite, muscovite, chlorite, and zircon.

The measured XRD pattern the assignments of the minerals is shown in Fig. 4(c). The Rietveld analysis was

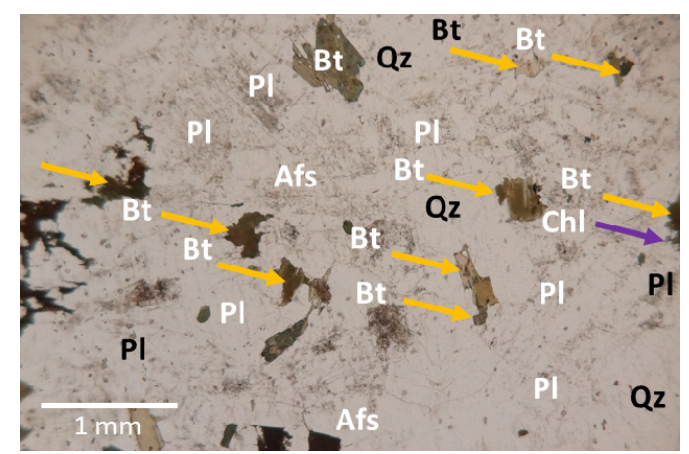

(a)

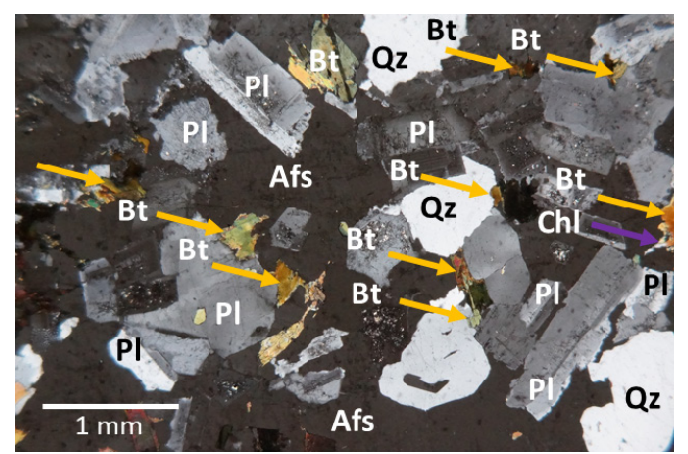

(b)

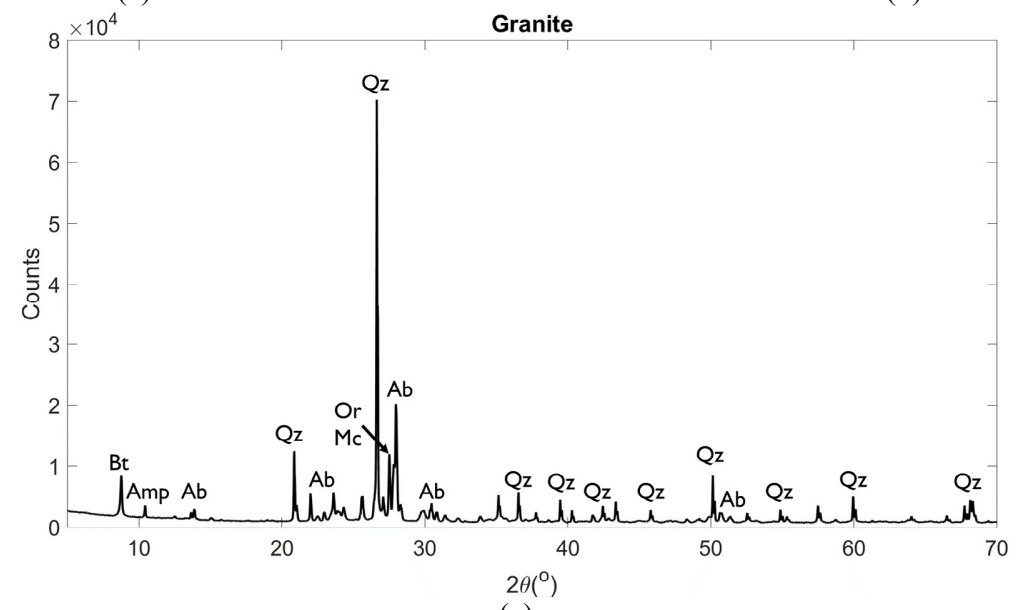

(c)

Fig. 4 (a) Micrograph under PPL for granite thin section, (b) Micrograph under XPL for granite thin section, (abbreviations: Qz for quartz, PI for plagioclase, Afs for alkali-feldspars, Bt for biotite and Chl for chlorite), (c) Experimental and fitted X-Ray diffraction pattern for the granite with the dominant phase (abbreviations: Qz for quartz, Ab for albite, Or for orthoclase, Mc for microcline, Amp for amphibole and Bt for biotite). 
performed with the following parameters $\mathrm{R}_{\exp }=2.47$, $\mathrm{R}_{\mathrm{wp}}=11.66$ and $\mathrm{GoF}=4.72$. The feldspars were identified as albite, microcline, and orthoclase. In addition, the presence of quartz was confirmed as well as that of biotite. Some other minor minerals were detected and are presented in Table 4. The composition of minerals is similar for dominant phases between the three methods (quartz, plagioclase, and alkali-feldspars). The biotite detected by the point counting method is higher compared to the XRD method. The remaining minor phases are in similar range for both methods if the standard deviation is considered. The XRD amorphous phase for this rock is very low which is comparable to its no detection by the point counting method.

The measured density of granite is equal to $2.655 \pm$ 0.003 and that calculated based on the XRD/Rietveld analysis is equal to 2.643 . The difference between both values is very low: $0.45 \%$, which can be considered as a complementary confirmation of the obtained phases identification and quantification.

\subsection{Metachert}

The XRF gives a very high percentage of $\mathrm{SiO}_{2} 94 \%$ as shown in Table 1. This is the highest percentage of this oxide among the studied rocks which is a very strong indicator of the high percentage of quartz in this metachert. The CIPW norm confirms quartz as the major phase, in addition to some other minerals.

The thin section of the metachert under the PPL and XPL is presented in Figs. 5(a) and (b). To measure the very small size of the grains in this rock, the $\mathrm{x} 10$ objective is used. The size of the grains is around 20-30 $\mu \mathrm{m}$. The quantification of the phases by the point counting method is gathered in Table 5. The quartz is the major mineral with approximately $84 \%$ of the counted points. $8 \%$ of mica is observed with $4 \%$ of chlorite and $4 \%$ of muscovite.

The XRD curve of the metachert is presented in Fig. 5(c), it is like that of pure quartz as observed with the identified peaks. The experimental chart was reproduced by the Rietveld method with the following parameters: $\mathrm{R}_{\text {exp }}=2.57, \mathrm{R}_{\mathrm{wp}}=8.98$ and $\mathrm{GoF}=3.50$ ). The Rietveld analysis results are presented in Table 5, confirming the high quartz content $(97.55 \%)$, the remaining content is mainly identified as amorphous.

The measured density is equal to $2.648 \pm 0.007$ and the calculated one is equal to 2.637 . This difference of $0.42 \%$ is an additional indicator of the purity of this metachert with a very high percentage of crystal quartz.

\subsection{Basalt}

The oxides measured by XRF method contained in the basalt is presented in Table 1. The percentage of $\mathrm{SiO}_{2}$ is around $42 \%$ which is very low compared to the previous rocks. It can be a sign of quartz absence in this rock. The CIPW norm for this rock is presented in Table 6, with high percentage for plagioclase which is a combination of albite and anorthite in this method. The next important phase detected is the olivine and then pyroxene considered as diopside.

The thin section for the basalt under PPL and XPL is presented in the Figs. 6(a) and (b). With $\mathrm{x} 4$ objective some big inclusions can be observed with an order of the grain size of $1 \mathrm{~mm}$. However, the major grains of this rock have dimensions inferior to this value which were determined by more accurate objective $\mathrm{x} 10$. Some pyroxenes with small dimensions (between $60 \mu \mathrm{m}$ and 140 $\mu \mathrm{m})$ have been observed as well as olivine (around 80 $\mu \mathrm{m})$. The mineral composition of basalt obtained by point counting method is given in Table 6.

Many crystal structures have been tested to fit the experimental XRD pattern and the identified phases are presented in Fig. 6(c). The parameters of fitting in this case are: $R_{\exp }=2.27, R_{w p}=7.79$ and $G o F=3.44$. The found minerals with their weight percentages are presented in Table 6. A low percentage of amorphous has been detected by this way and the major phases (plagioclase and pyroxene) have the same order by these last two methods. However, higher content of opaque minerals and olivine was detected by the point counting method. The plagioclase has been identified as a mixture of andesine and labradorite, the pyroxene as a combination of augite and diopside. The olivine corresponds to forsterite and the smectite to hectorite. The opaque minerals observed in thin section were assigned to magnetite and ilmenite.

The final confirmation test is the density calculation based on the XRD/Rietveld analysis results. The obtained density in this case was equal to 2.910 which is lower by $0.10 \%$ than the measured density equal to 2.913 \pm 0.008 . This result represents an additional confirmation for the presented identification and quantification of minerals inside the studied basalt.

\subsection{Andesite}

The oxides composition given by the XRF method is given in Table 1. The $\mathrm{SiO}_{2}$ percentage equal to $58 \%$ which is very low compared to the rocks containing quartz that can be an indicator of its absence. The CIPW norm is presented in Table 7. The plagioclase is found as a combination of albite and anorthite. The identified pyroxene is a mixture of hypersthene and diopside. The remaining content is composed from quartz, orthoclase, and some minor phases.

The thin section of andesite under PPL and XPL is given in the Figs. 7(a) and (b). Big inclusions are observed in these images like the plagioclase with grain size greater than $1.60 \mathrm{~mm}$. pyroxene grains superior in size $0.80 \mathrm{~mm}$ are detected. Big glassy content can also be seen in the pictures. The phase quantification obtained by the point counting method is presented in Table 7. Based on this method, three phases are determined as predominant: plagioclase $(37 \%)$, pyroxene $(35 \%)$ and amorphous phase (26\%). Other phases (smectite and opaque mineral) are detected but their contents are very low.

The identified peaks of the experimental XRD charts are presented in Fig. 7(c). The quality of the 
Table 5 Phase composition of metachert given by point-counting on thin section and XRD/Rietveld analysis.

\begin{tabular}{|c|c|c|c|c|c|c|c|}
\hline \multirow[b]{2}{*}{ Phase } & \multirow[b]{2}{*}{ Chemical formula } & \multirow[b]{2}{*}{ Density } & \multirow{2}{*}{$\begin{array}{c}\text { CIPW } \\
\text { Wt } \\
(\%)\end{array}$} & \multicolumn{2}{|c|}{ Thin section } & \multicolumn{2}{|c|}{ XRD/Rietveld } \\
\hline & & & & $\begin{array}{c}\text { Count } \\
(\%)\end{array}$ & $\begin{array}{l}\text { SD } \\
(\%)\end{array}$ & $\begin{array}{l}\mathrm{Wt} \\
(\%)\end{array}$ & $\mathrm{SD}(\%)$ \\
\hline Quartz & $\mathrm{SiO}_{2}$ & 2.65 & 88.55 & 84.0 & 2.1 & 97.55 & 2.09 \\
\hline Mica: biotite & $\mathrm{K}(\mathrm{Mg}, \mathrm{Fe})_{3}(\mathrm{OH}, \mathrm{F})_{2}\left(\mathrm{Si}_{3} \mathrm{AlO}_{10}\right)$ & 3.09 & - & 8.0 & 1.7 & 0.33 & 0.03 \\
\hline Staurolite & $\mathrm{Fe}^{2+} 2 \mathrm{Al}_{9} \mathrm{O}_{6}\left(\mathrm{SiO}_{4}\right)_{4}(\mathrm{O}, \mathrm{OH})$ & 3.75 & - & - & - & 0.03 & 0.00 \\
\hline Chlorite & $(\mathrm{Fe}, \mathrm{Mg}, \mathrm{Al})_{6}(\mathrm{Si}, \mathrm{Al})_{4} \mathrm{O}_{10}(\mathrm{OH})_{8}$ & 2.95 & - & 4.0 & 1.7 & - & - \\
\hline Muscovite & $\mathrm{KAl}_{2}\left(\mathrm{AlSi}_{3} \mathrm{O}_{10}\right)(\mathrm{OH}, \mathrm{F})_{2}$ & 2.82 & - & 2.0 & 0.8 & - & - \\
\hline Opaque minerals & - & - & - & 2.0 & 0.9 & - & - \\
\hline Other & - & - & 10.73 & - & - & - & - \\
\hline Amorphous & - & - & - & - & - & 2.09 & 2.08 \\
\hline Total & & & 99.28 & 100 & & 100 & \\
\hline
\end{tabular}

$\mathrm{XRD} /$ Rietveld analysis can be reflected in the following parameters: $R_{\exp }=2.36, R_{w p}=6.30$ and $\mathrm{GoF}=2.67$. The major phases detected by this method are like that detected by the thin section microscopy but with different proportions. The plagioclase content is lower and pyroxene fraction higher by the point counting method. The minor phases detected by this method are opaque minerals and Smectite while those given by the $\mathrm{XRD} /$ Rietveld analysis are magnetite and zircon as shown in Table 7. The plagioclase is identified as labradorite $(44 \%)$ and albite $(3 \%)$. The pyroxene corresponds to augite $(10 \%)$ and pigeonite $(2 \%)$. Zircon is also detected as a minor phase by the XRD analysis. Contrary to the CIPW norm, for both last methods, neither quartz nor orthoclase are found. Finally, despite the amorphous is detected by the point counting method ( $26 \%)$, its value still way far from the percentage obtained by the XRD method (41\%).

The calculated density is equal to 2.812 which is $4.73 \%$ higher than the measured density equal to $2.685 \pm$ 0.011 . This overestimation of the density is due to the high amorphous content in the rock which is not considered in the calculation. Indeed, the amorphous phases have generally a lower density which explains the lower value of the measured density.

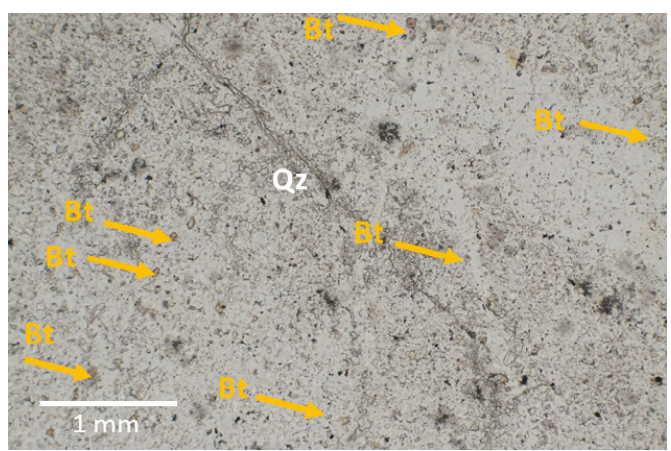

(a)

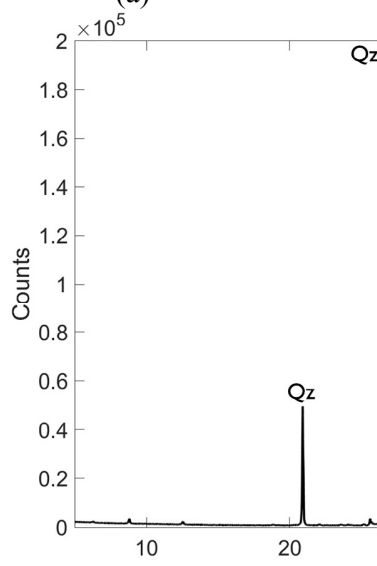

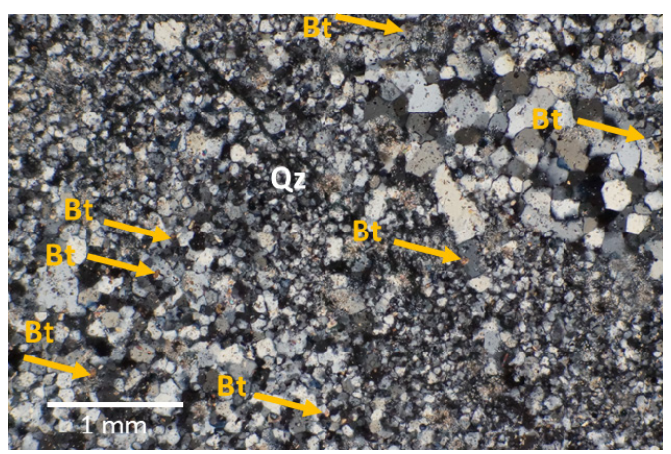

(b)

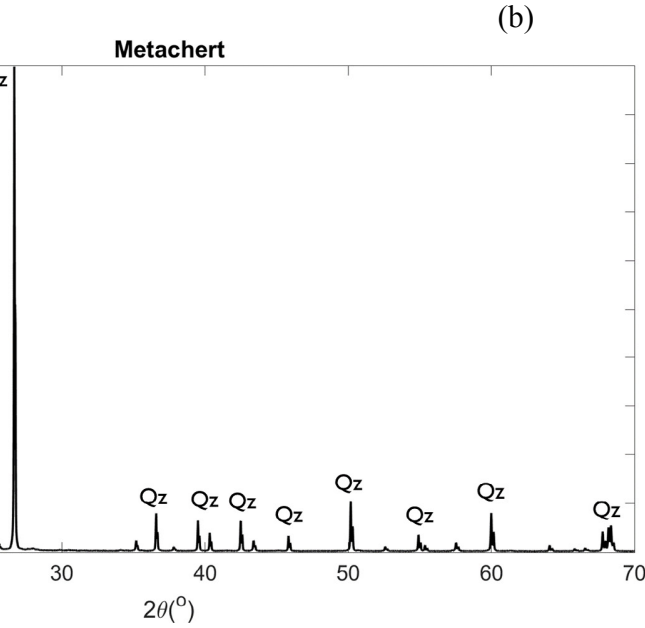

(c)

Fig. 5 (a) Micrograph under PPL for metachert thin section, (abbreviations: Qz for quartz and Bt for biotite), (b) Micrograph under XPL for metachert thin section, (c) Experimental and fitted X-Ray diffraction pattern for the metachert with the dominant phase (abbreviations: Qz for quartz). 
Table 6 Phase composition of basalt given by point-counting on thin section and XRD/Rietveld analysis.

\begin{tabular}{|c|c|c|c|c|c|c|c|}
\hline \multirow[b]{2}{*}{ Phase } & \multirow[b]{2}{*}{ Chemical formula } & \multirow[b]{2}{*}{ Density } & \multirow{2}{*}{$\begin{array}{c}\text { CIPW } \\
\mathrm{Wt} \\
(\%) \\
\end{array}$} & \multicolumn{2}{|c|}{ Thin section } & \multicolumn{2}{|c|}{ XRD/Rietveld } \\
\hline & & & & $\begin{array}{c}\text { Count } \\
(\%)\end{array}$ & $\begin{array}{l}\text { SD } \\
(\%)\end{array}$ & $\begin{array}{l}\mathrm{Wt} \\
(\%)\end{array}$ & $\begin{array}{l}\text { SD } \\
(\%)\end{array}$ \\
\hline $\begin{array}{l}\text { Plagioclase: } \\
\text { Andesine } \\
\text { Labradorite }\end{array}$ & $\begin{array}{l}(\mathrm{Ca}, \mathrm{Na})(\mathrm{Al}, \mathrm{Si})_{4} \mathrm{O}_{8} \\
(\mathrm{Na}, \mathrm{Ca})(\mathrm{Al}, \mathrm{Si})_{4} \mathrm{O}_{8}\end{array}$ & $\begin{array}{l}2.67 \\
2.69\end{array}$ & 40.74 & 48.6 & 4.2 & $\begin{array}{c}57.33= \\
17.67+ \\
39.67\end{array}$ & $\begin{array}{c}1.72= \\
0.47+ \\
1.25\end{array}$ \\
\hline $\begin{array}{l}\text { Pyroxene: } \\
\text { Augite } \\
\text { Diopside }\end{array}$ & $\begin{array}{c}\left((\mathrm{Si}, \mathrm{Al})_{2} \mathrm{O}_{6}\right)(\mathrm{Ca}, \mathrm{Mg}, \mathrm{Fe}, \mathrm{Ti}, \mathrm{Al})_{2} \\
\mathrm{MgCaSi}_{2} \mathrm{O}_{6}\end{array}$ & $\begin{array}{c}3.40 \\
3.278\end{array}$ & 13.77 & 23.2 & 3.1 & $\begin{array}{c}24.43= \\
17.17+ \\
7.27\end{array}$ & $\begin{array}{c}1.40= \\
0.95+ \\
0.45\end{array}$ \\
\hline Olivine (forsterite) & $\mathrm{Mg}_{2} \mathrm{SiO}_{4}$ & 3.27 & 17.81 & 12.8 & 1.7 & 6.5 & 0.08 \\
\hline $\begin{array}{c}\text { Opaque Mineral: } \\
\text { Magnetite } \\
\text { Ilmenite }\end{array}$ & $\begin{array}{c}\mathrm{Fe}_{3} \mathrm{O}_{4} \\
\mathrm{FeTiO}_{3}\end{array}$ & $\begin{array}{c}5.15 \\
4.789 \\
\end{array}$ & 0.74 & 11.9 & 1.6 & $\begin{array}{c}2.92= \\
1.52+ \\
1.4\end{array}$ & $\begin{array}{c}0.24= \\
0.08+ \\
0.16 \\
\end{array}$ \\
\hline Smectite (Hectorite) & $\mathrm{Na}_{0.3}(\mathrm{Mg}, \mathrm{Li})_{3} \mathrm{Si}_{4} \mathrm{O}_{10}(\mathrm{OH})_{2}$ & 2.5 & 3.29 & 3.5 & 1.3 & 2.3 & 0.16 \\
\hline Other & - & - & 10.96 & - & - & - & - \\
\hline Amorphous & - & - & - & - & - & 6.52 & 2.94 \\
\hline Total & & & 87.31 & 100 & & 100 & \\
\hline
\end{tabular}

\subsection{Sandstone}

The oxides composition of the sandstone is presented in the Table 1. High percentage of $\mathrm{SiO}_{2}$ corresponding to a probable existence of quartz inside the rock. Despite the sandstone is a sedimentary rock and the classic CIPW norm is not suitable for this category of rocks, the modal analysis is done by this method (Table 8) and can be considered as an indicative calculation. The rock is found to be composed from three major phases: plagioclase (albite $37.12 \%$ and anorthite 5.93\%), quartz (27.95\%) and alkali-feldspar (15.25\%) which is taken as orthoclase for this method.

The thin section of sandstone under PPL and XPL is shown in Figs. 8(a) and (b). The rock has clearly a

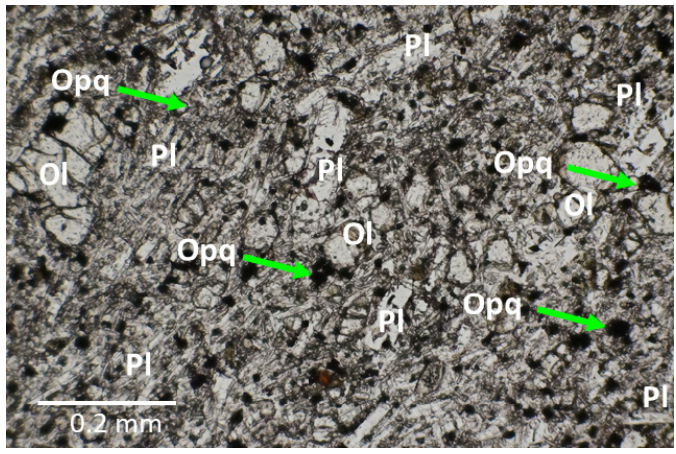

(a)

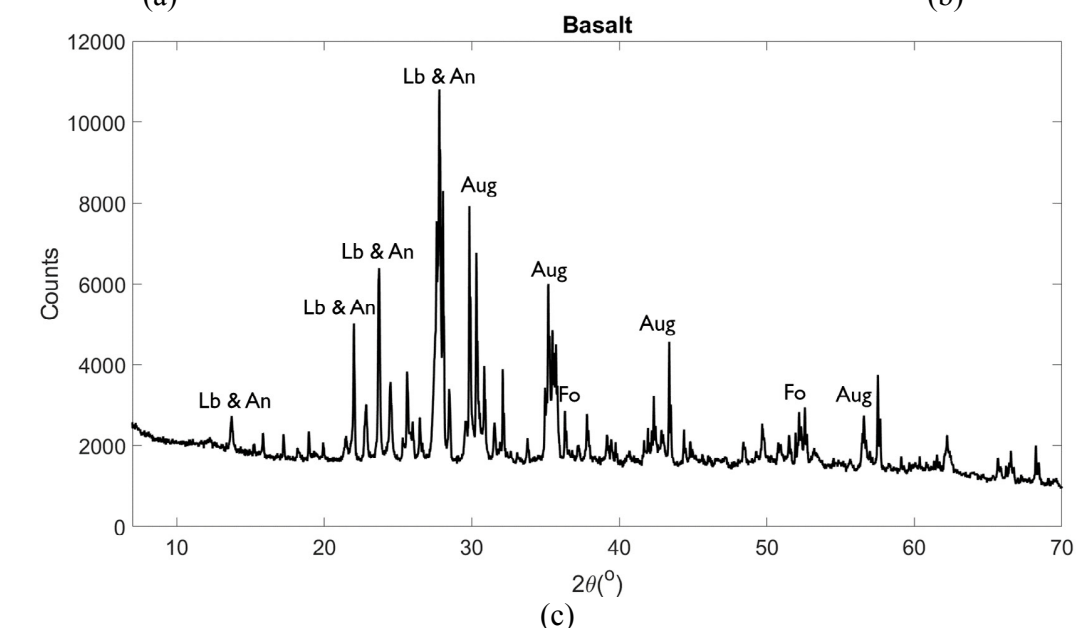

(c)

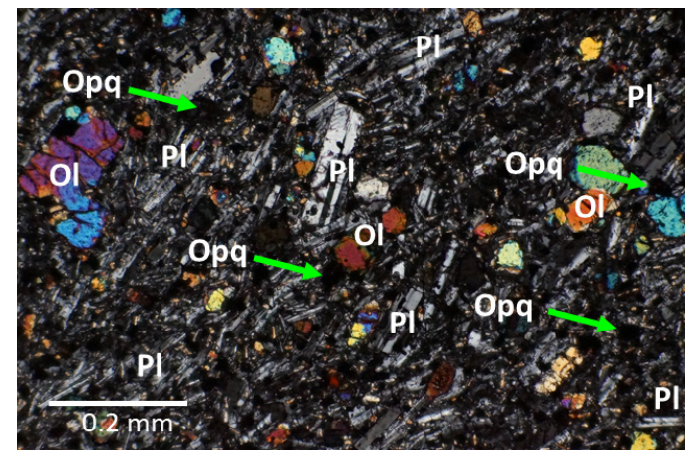

(b)

Fig. 6 (a) Micrograph under PPL for basalt thin section, (b) Micrograph under XPL for basalt thin section, (abbreviations: PI for plagioclase, OI for olivine and Opq for opaque minerals), (c) Experimental and fitted X-Ray diffraction pattern for the basalt with the dominant phase (abbreviations: Lb for labradorite, An for andesine, Aug for augite and Fo for forsterite). 
Table 7 Phase composition of andesite given by point-counting on thin section and XRD/Rietveld analysis.

\begin{tabular}{|c|c|c|c|c|c|c|c|}
\hline \multirow[b]{2}{*}{ Phase } & \multirow[b]{2}{*}{ Chemical formula } & \multirow[b]{2}{*}{ Density } & \multirow{2}{*}{$\begin{array}{c}\text { CIPW } \\
\mathrm{Wt} \\
(\%)\end{array}$} & \multicolumn{2}{|c|}{ Thin section } & \multicolumn{2}{|c|}{ XRD/Rietveld } \\
\hline & & & & $\begin{array}{l}\text { Count } \\
(\%)\end{array}$ & $\begin{array}{l}\text { SD } \\
(\%)\end{array}$ & $\begin{array}{l}\text { Wt } \\
(\%)\end{array}$ & $\begin{array}{l}\text { SD } \\
(\%)\end{array}$ \\
\hline $\begin{array}{c}\text { Plagioclase: } \\
\text { Albite+ } \\
\text { Labradorite }\end{array}$ & $\begin{array}{c}\mathrm{NaAlSi}_{3} \mathrm{O}_{8} \\
(\mathrm{Na}, \mathrm{Ca})(\mathrm{Al}, \mathrm{Si})_{4} \mathrm{O}_{8}\end{array}$ & $\begin{array}{l}2.62 \\
2.69\end{array}$ & 48.67 & 37.0 & 2.4 & $\begin{array}{c}47.03= \\
2.97+ \\
44.06\end{array}$ & $\begin{array}{c}0.92= \\
0.28+ \\
0.65\end{array}$ \\
\hline $\begin{array}{l}\text { Pyroxene: } \\
\text { Augite+ } \\
\text { Pigeonite }\end{array}$ & $\begin{array}{c}\left((\mathrm{Si}, \mathrm{Al})_{2} \mathrm{O}_{6}\right)(\mathrm{Ca}, \mathrm{Mg}, \mathrm{Fe}, \mathrm{Ti}, \mathrm{Al})_{2} \\
(\mathrm{Ca}, \mathrm{Mg}, \mathrm{Fe})(\mathrm{Mg}, \mathrm{Fe}) \mathrm{Si}_{2} \mathrm{O}_{6}\end{array}$ & $\begin{array}{c}3.4 \\
3.38\end{array}$ & 22.85 & 34.8 & 2.3 & $\begin{array}{c}11.77= \\
10.11+ \\
1.67\end{array}$ & $\begin{array}{c}0.39= \\
030+ \\
0.09\end{array}$ \\
\hline $\begin{array}{l}\text { Opaque mineral } \\
\text { (magnetite) }\end{array}$ & $\mathrm{Fe}_{3} \mathrm{O}_{4}$ & 5.15 & 0.51 & 1.3 & 0.8 & 0.29 & 0.06 \\
\hline Smectite & - & 2.35 & - & 0.4 & 0.5 & - & - \\
\hline Zircon & $\mathrm{ZrSiO}_{4}$ & 4.65 & - & - & - & 0.13 & 0.02 \\
\hline Other & - & - & 25.30 & - & - & - & - \\
\hline Amorphous & - & - & - & 26.5 & 3.3 & 40.77 & 0.61 \\
\hline Total & & & 97.33 & 100 & & 100 & \\
\hline
\end{tabular}

granular nature. To measure the size of these grains, the 10x objective was also used. The plagioclase and quartz order of their grains' size is under $100 \mu \mathrm{m}$. The phase quantification estimated by the point counting method is presented in the Table 8. The major phase is quartz with $53 \%$ of weight fraction. High content of clay minerals was also observed $(17 \%)$ as well as of alkali-feldspar $(9 \%)$. The minor phases detected in this thin section are opaque minerals (4\%) and calcite (4\%). No glass phase was observed in this sandstone.

The experimental XRD curve with the identified phases is presented in Fig. 8(c). The parameters related to the quality of the fitting are $R_{\exp }=2.47, R_{w p}=9.26$ and $\mathrm{GoF}=3.75$. As described in Table 8, this rock contains oligoclase (44\%), quartz (32\%), orthoclase (14\%), chlorite $(7 \%)$ with small percentage of microcline and biotite. Higher percentage of quartz, clay minerals and lower content of feldspar were detected in the thin section. Also,

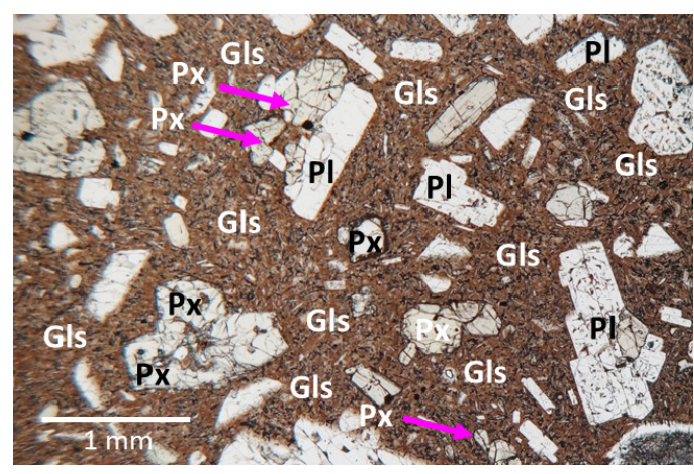

(a)

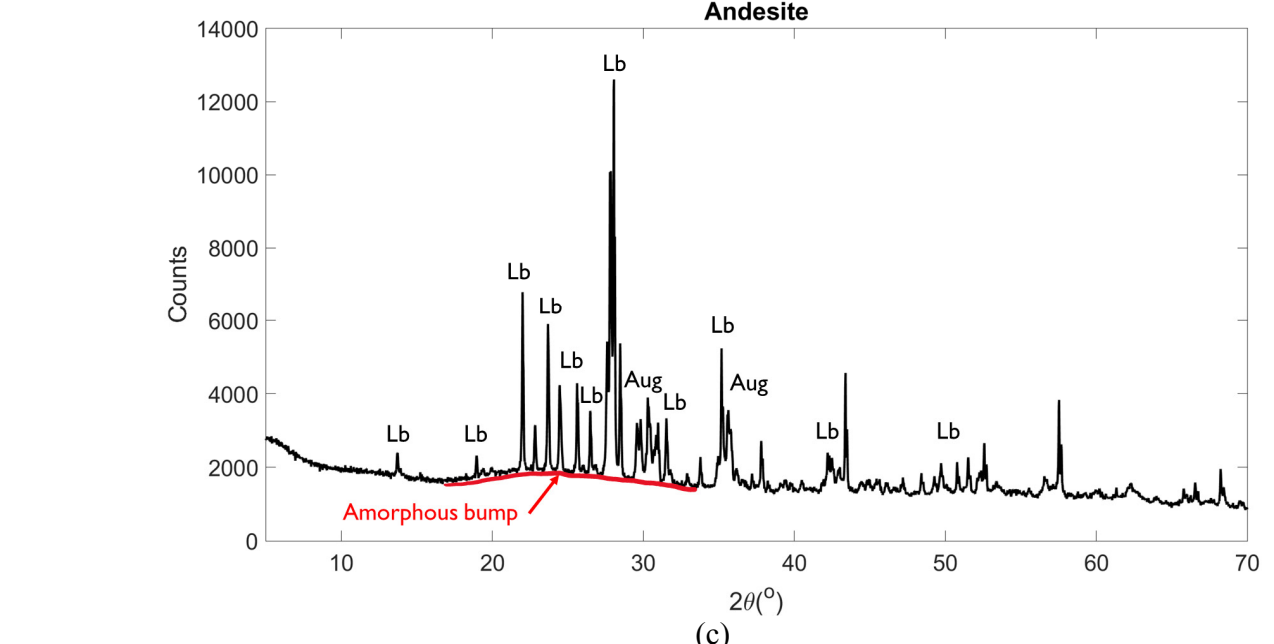

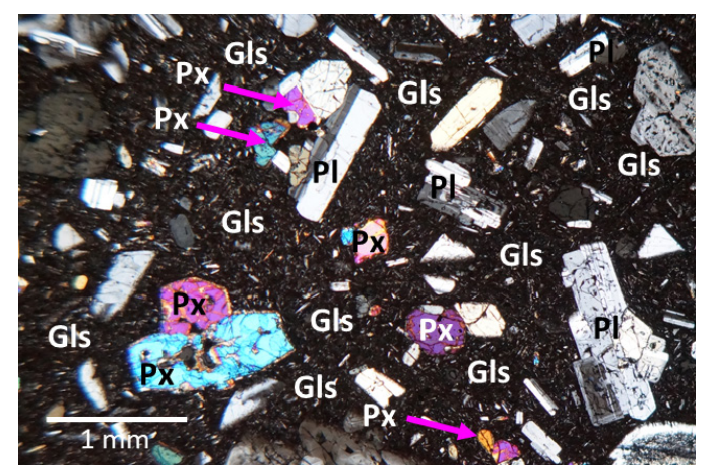

(b)

Andesite

Fig. 7 (a) Micrograph under PPL for andesite thin section, (abbreviations: Px for pyroxene, PI for plagioclase and Gls for glassy phases), (b) Micrograph under XPL for andesite thin section, (c) Experimental and fitted X-Ray diffraction pattern for the andesite with the dominant phase (abbreviations: Lb for labradorite and Aug for augite). 
Table 8 Phase composition of sandstone given by point-counting on thin section and XRD/Rietveld analysis.

\begin{tabular}{|c|c|c|c|c|c|c|c|}
\hline \multirow[b]{2}{*}{ Phase } & \multirow[b]{2}{*}{ Chemical formula } & \multirow[b]{2}{*}{ Density } & \multirow{2}{*}{$\begin{array}{c}\text { CIPW } \\
\mathrm{Wt} \\
(\%)\end{array}$} & \multicolumn{2}{|c|}{ Thin section } & \multicolumn{2}{|c|}{ XRD/Rietveld } \\
\hline & & & & $\begin{array}{c}\text { Count } \\
(\%)\end{array}$ & $\begin{array}{l}\text { SD } \\
(\%)\end{array}$ & $\begin{array}{l}\mathrm{Wt} \\
(\%)\end{array}$ & $\begin{array}{l}\text { SD } \\
(\%)\end{array}$ \\
\hline Quartz & $\mathrm{SiO}_{2}$ & 2.65 & 27.95 & 52.6 & 2.9 & 31.65 & 1.12 \\
\hline $\begin{array}{c}\text { Clay minerals: } \\
\text { Chlorite }\end{array}$ & $(\mathrm{Fe}, \mathrm{Mg}, \mathrm{Al})_{6}(\mathrm{Si}, \mathrm{Al})_{4} \mathrm{O}_{10}(\mathrm{OH})_{8}$ & 2.95 & - & 17.5 & 3.8 & 7.33 & 0.18 \\
\hline $\begin{array}{c}\text { Plagioclase } \\
\text { Oligoclase }\end{array}$ & $(\mathrm{Na}, \mathrm{Ca})[\mathrm{Al}(\mathrm{Si}, \mathrm{Al}) \mathrm{Si}]_{2} \mathrm{O}_{8}$ & 2.65 & 43.04 & 12.4 & 3.7 & 43.69 & 1.30 \\
\hline $\begin{array}{l}\text { Alkali-feldspar: } \\
\text { Microcline Ortho- } \\
\text { clase }\end{array}$ & $\mathrm{KAlSi}_{3} \mathrm{O}_{8}$ & 2.56 & 15.25 & 9.4 & 2.4 & $\begin{array}{l}15.22= \\
1.12+ \\
14.10\end{array}$ & $\begin{array}{c}0.29= \\
0.12+ \\
0.17\end{array}$ \\
\hline Opaque mineral & - & - & - & 4.3 & 1.8 & - & - \\
\hline Calcite & $\mathrm{CaCO}_{3}$ & 2.71 & - & 3.8 & 1.8 & - & - \\
\hline Biotite & $\mathrm{K}(\mathrm{Mg}, \mathrm{Fe})_{3}(\mathrm{OH}, \mathrm{F})_{2}\left(\mathrm{Si}_{3} \mathrm{AlO}_{10}\right)$ & 3.09 & - & - & - & 0.69 & 0.01 \\
\hline Other & - & - & 11.39 & - & - & - & - \\
\hline Amorphous & - & - & - & - & - & 1.42 & 2.35 \\
\hline Total & & & 97.63 & 100 & & 100 & \\
\hline
\end{tabular}

the minor phases of opaque minerals and calcite were found in thin section but not in the XRD results. Biotite in contrary, was only detected in small portion by the XRD method. The biggest difference in the result between both last methods has been registered for this rock. As explained before, this difference can be related to the heterogeneity of rocks reflected in the sampling. The
CIPW method provides in this case a reasonable result but without considering the clay minerals which can be problematic in case of high proportion.

The density calculated based on the XRD/Rietveld analysis results is equal to 2.658 that is only lower by $0.11 \%$ than the measured density $2.661 \pm 0.003$. This value can be considered as an additional confirmation of

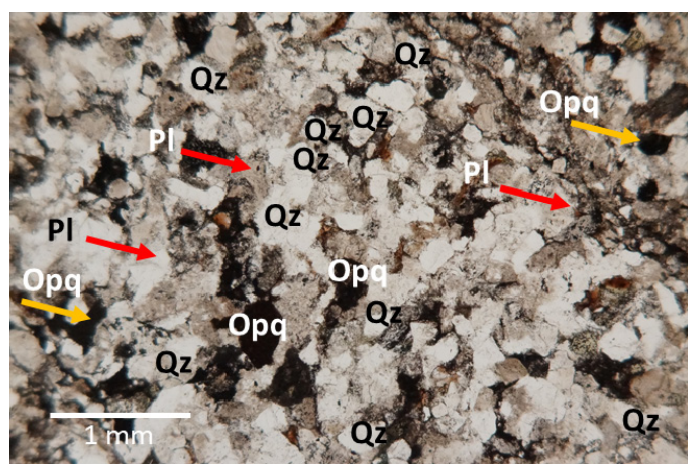

(a)

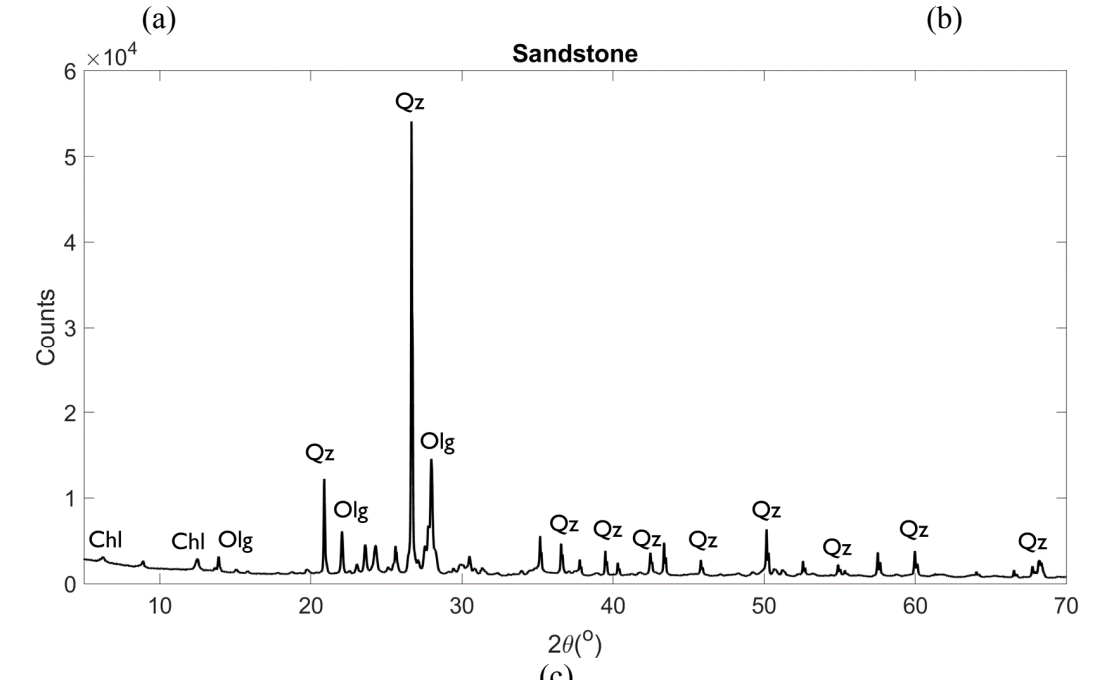

(c)

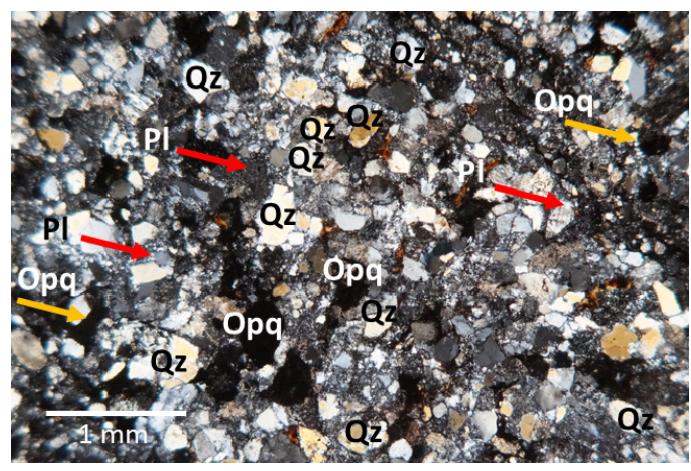

(b)

Fig. 8 (a) Micrograph under PPL for sandstone thin section, (abbreviations: Qz for quartz, PI for plagioclase and Opq for opaque minerals), (b) Micrograph under XPL for sandstone thin section, (c) Experimental and fitted X-Ray diffraction pattern for the sandstone with the dominant phase (abbreviations: Qz for quartz, Chl for chlorite and Olg for oligoclase). 
Table 9 Phase composition of peridotite given by point-counting on thin section and XRD/Rietveld analysis.

\begin{tabular}{|c|c|c|c|c|c|c|c|}
\hline \multirow[b]{2}{*}{ Phase } & \multirow[b]{2}{*}{ Chemical formula } & \multirow[b]{2}{*}{ Density } & \multirow{2}{*}{$\begin{array}{c}\text { CIPW } \\
\mathrm{Wt} \\
(\%)\end{array}$} & \multicolumn{2}{|c|}{ Thin section } & \multicolumn{2}{|c|}{ XRD/Rietveld } \\
\hline & & & & $\begin{array}{c}\text { Count } \\
(\%)\end{array}$ & $\begin{array}{l}\text { SD } \\
(\%)\end{array}$ & $\begin{array}{l}\text { Wt } \\
(\%)\end{array}$ & $\begin{array}{l}\text { SD } \\
(\%)\end{array}$ \\
\hline Olivine (forsterite) & $\mathrm{Mg}_{2} \mathrm{SiO}_{4}$ & 3.27 & 84.88 & 85 & 7.7 & 80.67 & 2.62 \\
\hline Carbonate mineral: & & & & 9.9 & 3.7 & $1.88=$ & $0.29=$ \\
\hline Azurite & $\mathrm{Cu}_{3}\left(\mathrm{CO}_{3}\right)_{2}(\mathrm{OH})_{2}$ & 3.83 & & & & $0.68+$ & $0.10+$ \\
\hline Malachite & $\mathrm{Cu}_{2}\left(\mathrm{CO}_{3}\right)(\mathrm{OH})_{2}$ & 3.8 & - & & & $0.31+$ & $0.02+$ \\
\hline Hydrozincite & $\mathrm{Zn}_{5}\left(\mathrm{CO}_{3}\right)_{2}(\mathrm{OH})_{6}$ & 3.37 & & & & 0.87 & 0.17 \\
\hline Serpentinite (lizardite) & $\mathrm{Mg}_{3}\left(\mathrm{Si}_{2} \mathrm{O}_{5}\right)(\mathrm{OH})_{4}$ & 2.58 & - & 1.9 & 2.9 & 2.73 & 0.25 \\
\hline Talc & $\mathrm{Mg}_{3} \mathrm{Si}_{4} \mathrm{O}_{10}(\mathrm{OH})_{2}$ & 2.75 & - & 1.7 & 3.0 & 3.7 & 0.67 \\
\hline Onaque mineral. & & & & 1.0 & 0.9 & $2.15=$ & $0.55=$ \\
\hline Hematite & $\mathrm{Fe}_{2} \mathrm{O}_{3}$ & 5.3 & & & & $0.18+$ & $0.05+$ \\
\hline Ilmenite & $\mathrm{FeTiO}_{3}$ & 4.789 & & & & $0.87+$ & $0.21+$ \\
\hline Magnetite & $\mathrm{Fe}_{3} \mathrm{O}_{4}$ & 5.2 & 0.64 & & & 1.10 & 0.29 \\
\hline Spinel & $\mathrm{MgAl}_{2} \mathrm{O}_{4}$ & 3.65 & - & 0.5 & 1.2 & 0.07 & 0.01 \\
\hline Other & - & - & 10.04 & - & - & - & - \\
\hline Amorphous & - & - & - & - & - & 8.81 & 1.86 \\
\hline Total & & & 95.56 & 100 & & 100 & \\
\hline
\end{tabular}

the obtained results.

\subsection{Peridotite}

The peridotite is the only studied rock for which $\mathrm{SiO}_{2}$ is not the highest oxide content. The highest percentage is for $\mathrm{MgO}$ equal to $46 \%$ which is included in the olivine atomic composition. The $\mathrm{SiO}_{2}$ oxide content is the lowest among all the studied rocks which can be linked to the absence of quartz. The CIPW norm given in Table 9 presents composition of this rock with $85 \%$ of olivine in addition to hypersthene pyroxene $(8.7 \%)$ and some other minor phases as magnetite $(0.64 \%)$.

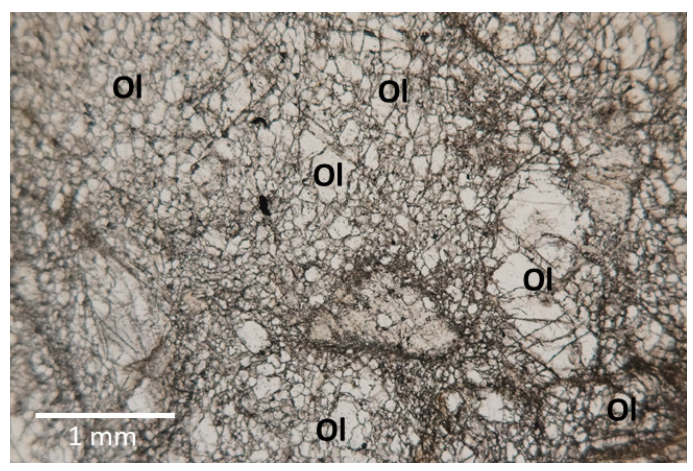

(a)

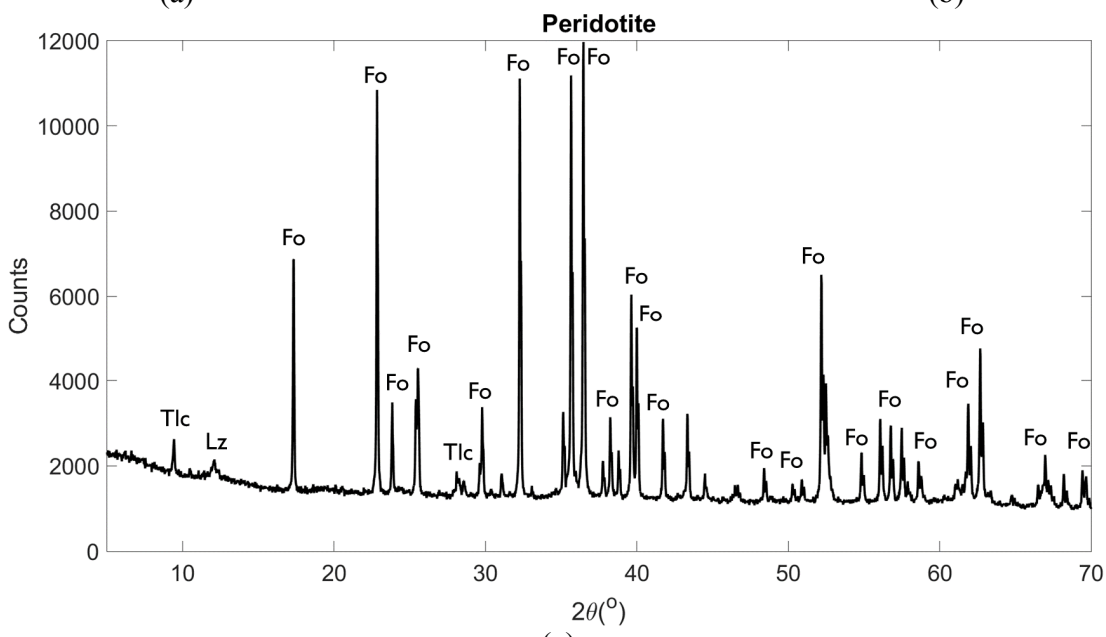

(c)

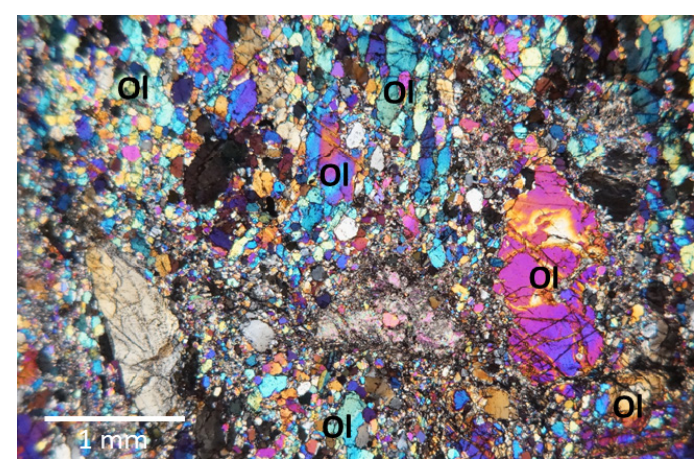

(b) 
The thin section of peridotite under PPL and XPL is presented in Figs. 9(a) and (b). The observed grains in this rock have different sizes. The big observed grains of olivine are in the order of $1 \mathrm{~mm}$ while the small grains are in the range of 10 to $100 \mu \mathrm{m}$. The mineral compositions given by point counting method is presented in Table 9. The major phase in this rock is olivine $85 \%$ and the minor phases are carbonate mineral $(10 \%)$, serpentinite $(2 \%)$, talc $(2 \%)$, opaque mineral $(1 \%)$ and spinel $(0.5 \%)$.

The XRD Rietveld analysis was performed based on the XRF description. The experimental curve with the assigned peaks is presented in Fig. 9(c). The parameters related to the quality of fitting are: $R_{\text {exp }}=2.50, R_{w p}=7.03$ and $\mathrm{GoF}=2.81$. olivine is identified as forsterite with $81 \%$ of content. The carbonate minerals are detected in low percentage as three different minerals: azurite, malachite and hydrozincite. The serpentinite is under the lizardite form. Also, three phases are identified as opaque minerals: hematite, ilmenite, and magnetite. The Phases quantification by the XRD/Rietveld analysis is presented in Table 9. For all methods, high amount of olivine was observed. The carbonate minerals content given by the thin section is higher than that obtained by XRD. Other percentage of minor phases stay in the standard deviation ranges. As for major studied rocks, no glass phases have been observed by the microscopy contrary to the Rietveld result.

The peridotite has the highest measured density value among the studied rocks with a value of $3.272 \pm 0.013$. The estimation of this density based on the phase identification and quantification provides a value of 3.252 which is a slightly lower $(0.61 \%)$ than the measured density. Here also, this value can be considered as an additional confirmation of the obtained results.

\section{Discussion}

For the eight studied rocks, the results obtained by the

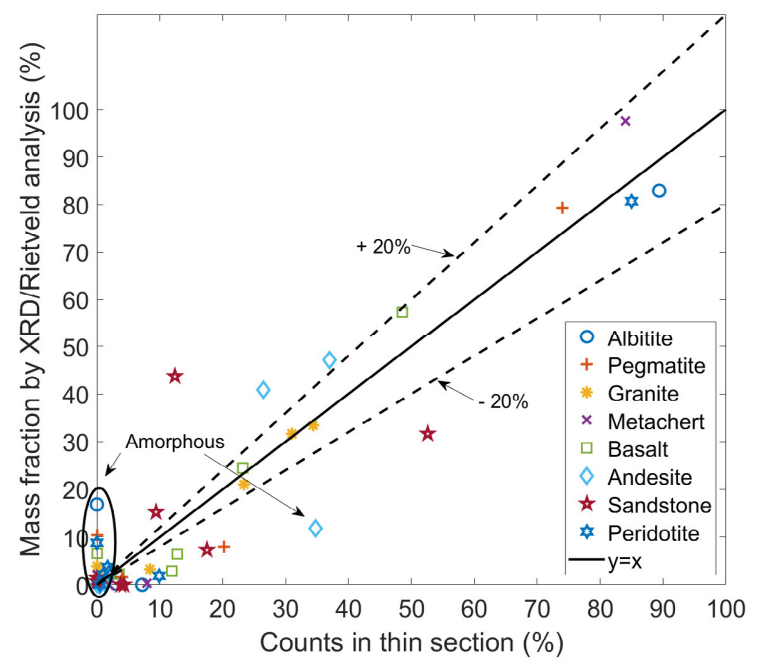

Fig. 10 Counts in thin section versus mass fraction given by XRD/Rietveld analysis.
XRD/Rietveld analysis are comparable to the those of the point counting method (Fig. 10). Concerning the phase identification, the dominant phases obtained by both methods are equivalent, especially in granite. However, in some rocks, some differences in the identification of minor phases (under 10\%) can be observed. It is the case of four rocks among eight: albitite, metachert, andesite and sandstone. For the albitite rock, quartz is only observed in the thin section $(7.2 \%)$. Concerning the metachert, very negligible amount of staurolite $(0.03 \%)$ is only shown with the Rietveld analysis while chlorite (4\%) and muscovite (4\%) are only shown by the point counting method. The andesite contains smectite $(0.4 \%)$ according to the thin section and zircon $(0.13 \%)$ by XRD. The last rock is sandstone which contains opaque mineral $(4.0 \%)$ and calcite $(3.8 \%)$ by point counting method while biotite $(0.69 \%)$ is detected by the XRD. For all studied rocks, the cumulative difference for the phases undetected separately by both methods is under $10 \%$ and can be as low as $0.53 \%$ in the andesite case. These small differences between both methods are not systematic and can be explained by the heterogeneity of rocks and the small size of samples used in both methods.

For the quantification of phases, the first remark concerns the high amorphous content given by the $\mathrm{XRD} /$ Rietveld analysis. This tendency can be related essentially to the fitting errors of calculation and partially to the reduction of the crystallinity according to the duration of the grinding process. In previous studies (Takahashi 1957; Kim et al. 2019; Hlavay et al. 1978), it has been confirmed that, the intensity of peaks as well as their broadening are decreasing with the grinding time. It is explained by the creation of an amorphous layer ( $30 \mathrm{~nm}$ ) during the powdering process known as Beilby-Bowden layer (Bowden and Hughes 1937; Castro et al. 2012). To reduce this error, it is important to enhance the procedure experimentally and numerically. Experimentally, the created amorphous phase should be reduced by a slower grinding time and using a wet grinding approach for instance. For the soft rocks in this study, a lapse of 30 seconds is at least required to obtain the powder with particle size distribution under $90 \mu \mathrm{m}$. for harder rocks, the powder obtained after one cycle is generally insufficient and up to four cycles can be necessary. To reduce the drop in crystallinity, the users are encouraged to add cycles of 30 seconds one by one until grinding completely the rock. Also, the time of data acquisition can be increased to have more accurate experimental XRD chart, but the quality vs acquisition time is an asymptotic curve and the gain in the quality of the curves will be limited compared to the longest time. Numerically, the minerals exist in natural rocks under solid solution form. The use of multiple raw files corresponding to different solutions can allow the selection of the most appropriate one for the analysis. In this case, the error will be reduced automatically, and the amorphous content will be minimized. Thus, compared to the thin sections, the analyzed powders taken from the same 
rocks have a higher amorphous content. In addition, for rocks with small amorphous content, the uncertainties given by the XRD/Rietveld analysis for the amorphous fraction becomes larger (Snellings et al. 2010). A higher amorphous content is equivalent to lower contents of crystalline material which can partially explain the underestimation by XRD method of some phases when high amorphous difference is detected between both methods. It is the case of pyroxene in andesite and all phases in albitite. Other examples are albite, quartz and white mica in pegmatite rock, olivine, and carbonate minerals in peridotite rock. Therefore, the most important factor behind this overestimation of the amorphous phase is the artefact linked to the Rietveld analysis for such well crystalized materials. The second remark concerns the calculation of the standard deviation which is based on 10 series of 100 points for the point counting method. The obtained values remain very high compared to that of the XRD/Rietveld analysis. Statistically, a higher accuracy can be obtained with more points, but the method is already time consuming and expensive. For the third remark, it should also be noticed that the quantification given by the XRD/Rietveld analysis corresponds to the mass fraction of minerals while that given by the point counting method is more related to their volume fraction. Thus, the thin section values should be higher (lower) than the values obtained by the XRD/Rietveld analysis for phases with a lower (higher) density compared to the rock density.

The major phases obtained by both methods are almost similar for all rocks except for sandstone. For this rock, the major mineral detected by the thin section observation is the quartz (52.6\%) while it is oligoclase (43.69\%) based on the XRD method. For intermediate phases, some discrepancies are noted between both tests.

The density measurements are used to confirm the results obtained by both methods. the obtained value is compared to the density calculated from the composition given by the $\mathrm{XRD} /$ Rietveld analysis. If the identification and the quantification are well done, the difference between both values should be low. For seven rocks with low amorphous phase, this difference is lower than $1 \%$ supporting the composition result. In the case of andesite, the difference is very high $(4.73 \%)$ which can be explained by the high amorphous content. Indeed, the density calculation is only based on the crystal phases because the minerals composing the amorphous part with their densities are generally unknown. Thus, the density is generally overestimated making the density confirmation test inappropriate in this case.

In the context of civil engineering laboratory, the approach based on the XRD/Rietveld analysis can certainly offer quick, accurate and accessible method for modal analysis of rock-forming minerals, although more accuracy is necessary for petrological studies. The results will be very useful for modelling concrete behavior especially when aggregates play a central role. It is the case when aggregates swell due to alkali silica reaction or irradia- tion. The modal analysis will allow to implement the properties of each mineral during modeling. For instance, the composing minerals can be associated with their corresponding tensors of elastic stiffness, elastic compliance, and coefficient of thermal expansion. To be the most representative of the aggregate's behavior, the content of the amorphous phase is also an important data to consider as input for the modeling. Generally, the amorphous phases are less sensitive to the environment conditions (temperature, radiation) compared to the crystal phases. The presented methods do not provide the composition of the amorphous phases, however the obtained percentage combined with the assumption of low sensitivity can be used as the best available input data for this modeling. Under different kind of external solicitations, the stress inside aggregates or concrete as well as the corresponding damage can be estimated properly. A such predictive calculation will certainly allow a better aging management of preexisting NPP and provide an interesting tool to discriminate aggregates according to their performances under different conditions for future infrastructures.

\section{Conclusion}

The point counting method for the identification and quantification of minerals inside rocks was compared in this paper to an approach based on the XRD/Rietveld analysis combined with XRF and CIPW norm as a pre-characterization test with a confirmation test: density measurement. This approach presents the advantage of being faster and less expensive allowing it to be more representative of the studied rocks by multiplying the number of tested samples. In addition, more detailed description of the composing minerals is given by this approach which is required in some advanced studies. This comparison was performed on eight rocks and the following conclusions can be shown:

1) The atomic composition obtained by XRF is a useful pre-characterization test. It allows combining with the knowledge about the geological nature of the rock to have a general idea of the composing minerals. In the case of a rock with a high quartz content, the identification can immediately be related to the high percentage of $\mathrm{SiO}_{2}$. The presence of feldspar requires a non-negligible percentage of $\mathrm{Al}_{2} \mathrm{O}_{3}$. In this case, a good indication of the composing feldspar minerals is deduced based on the proportion of $\mathrm{Na}_{2} \mathrm{O}, \mathrm{K}_{2} \mathrm{O}$ and $\mathrm{CaO}$. If high amount of some other oxides like Magnesium or iron are detected, the choice of minerals can be oriented to olivine, pyroxene, clay minerals or biotite for example. For more detailed description, the CIPW norm can be calculated and an optimized mineral composition can be obtained which should be used carefully.

2) The amorphous content obtained by the point counting method is systematically inferior to that given by the Rietveld analysis. In many cases, the glassy phase 
is not even observed by the microscope. This difference is mostly related to the cumulated errors during the fitting process. The powder preparation by grinding can also be partially accountable for the crystallinity reduction of the material. In the case that non negligible fraction of glassy phases exists in the rock, a mismatching between the measured density and the calculated one (based on the XRD/Rietveld analysis) should be observable.

3) The dominant phases obtained by both methods are generally similar with some differences in the obtained fractions. Some discrepancies are observed for the intermediate phases and more of them are registered for the minor phases. However, the standard deviation of the point counting method is very high compared to that of the XRD/Rietveld analysis, making an overlap between the values obtained by these methods especially for the minority minerals.

4) The comparison of the calculated density based on the results of XRD/Rietveld analysis with the measured density represents an efficient verification criterion. However, this method cannot be considered if the rock contains a high amount of amorphous. This result confirms that the detected amorphous phases provided by the XRD/Rietveld analysis is mostly related to the calculation artefact than other thing.

Finally, it can be concluded that the XRD/Rietveld analysis can represent a good alternative for the point counting method. Especially in the context of construction materials laboratory for which the XRD equipment and the analysis tools are already available. The experience of the users in the characterization of cementitious materials can be helpful for the case of rock forming minerals. This method becomes also more efficient for rocks with small grains undetectable by the microscope. It should also be noted that the complementary test like $\mathrm{XRF}$ and density measurements can be performed but are not necessary to obtain good modal analysis by XRD/Rietveld analysis.

\section{Acknowledgements}

The authors gratefully acknowledge the support of Ministry of Economy, Trade, and Industry (METI) in Japan, through the Japan Concrete Aging Management Program on Irradiation Effects (JCAMP). Thin section specimens were prepared by Ms. Natsuko Takagi, Technical Center of Nagoya University.

\section{References}

Alves, M. E., Mascarenhas, Y. P., French, D. H. and Vaz, C. P. M., (2007). "Rietveld-based mineralogical quantitation of deferrified oxisol clays." Australian Journal of Soil Research, 45(3), 224-232.

Bailey, S. W., (1969). "Refinement of an intermediate microcline structure." The American Mineralogist, 54(11-12), 1540-1545.

Bish, D. L. and Post, J. E., (1993). "Quantitative mineralogical analysis using the Rietveld full-pattern fitting method." American Mineralogist, 78(9-10), 932-940.

Bolse, W., (1999). "Amorphization and recrystallization of covalent tetrahedral networks." Nuclear Instruments and Methods in Physics Research, Section B: Beam Interactions with Materials and Atoms, 148(1-4), 83-92.

Bowden, F. and Hughes, T., (1937). "Physical properties of surfaces IV - polishing, surface flow and the formation of the Beilby layer." In: Proceedings of the Royal Society of London. Series A - Mathematical and Physical Sciences, 575-587.

Brinatti, A. M., Mascarenhas, Y. P., Pereira, V. P., Partiti, C. S. de M. and Macedo, Á., (2010). "Mineralogical characterization of a highly-weathered soil by the Rietveld method." Scientia Agricola, 67(4), 454-464.

Byers, F. M., Vaniman, D. T., Schempp, L. W., Nunes, H. P. and Herbst, R. J., (1990). "Procedure for determination of volume constituents in thin sections of rocks." TWS-ESS-DP-102, Los Alamos Naational Laboratory, R2, 1-8.

Bykov, V. N., Denisov, A. V., Dubrovskii, V. B., Korenevskii, V. V., Krivokoneva, G. K. and Muzalevskii, L. P., (1981). "Effect of irradiation temperature on the radiation expansion of quartz." Soviet Atomic Energy, 51, 593-595.

Castro, N., Sorensen, B. E. and Broekmans, M. A. T. M., (2012). "Quantitative assessment of alkali-reactive aggregate mineral content through XRD using polished sections as a supplementary tool to RILEM AAR-1 (petrographic method)." Cement and Concrete Research, 42(11), 1428-1437.

CEN-EN 12407, (2019). "Natural stone test methods Petrographic examination." Brussels, Belgium: European Committee for Standarization.

Cross, W., Iddings, J. P., Pirsson, L. V. and Washington, H. S., (1902). "A quantitative chemico-mineralogical classification and nomenclature of igneous rocks." The Journal of Geology, 10(6), 555-690.

Denisov, A., Dubrovskii, V. and Solovyov, V., (2012). "Radiation resistance of mineral and polymer construction materials." ZAO MEI Publishing House. (in Russian)

Douillard, L. and Duraud, J., (1996). “Amorphization of $\alpha$-Quartz under irradiation." Journal de physique III, 6(12), 1677-1687.

Downs, R. T. and Hall-Wallace, M., (2003) "The American mineralogist crystal structure database." American Mineralogist, 88, 247-250. Available at: http://rruff.geo.arizona.edu/AMS/amcsd.php.

Elleuch, F., Dubois, F. and Rappeneau, J., (1972). "Effects of neutron radiation on special concretes and their components." ACI Journal, 34, 1071-1108.

Ewing, R. C., (1994). "The metamict state: 1993 - the centennial." Nuclear Inst. and Methods in Physics Research, B, 91(1-4), 22-29.

Ewing, R. C., Meldrum, A., Wang, L. and Wang, S., (1987). "Radiation-induced amorphization." Reviews in 
Mineralogy and Geochemistry, 236(4808), 1556-1559.

Field, K. G., Remec, I. and Le Pape, Y., (2015).

"Radiation effects in concrete for nuclear power plants

- Part I: Quantification of radiation exposure and radiation effects." Nuclear Engineering and Design, 282, 126-143.

Grazulis, S., Chateigner, D., Downs, R. T., Yokochi, A. T., Quiros, M., Lutterotti, L., Manakova, E., Butkus, J., Moeck, P. and Le Bail, A., (2009). "Crystallography Open Database - an open-access collection of crystal structures." Journal of Applied Crystallography, 42, 726-729.

Gražulis, S., Daškevič, A., Merkys, A., Chateigner, D., Lutterotti, L., Quirós, M., Serebryanaya, N. R., Moeck, P., Downs, R. T. and LeBail, A., (2012). "Crystallography Open Database (COD): an open-access collection of crystal structures and platform for world-wide collaboration." Nucleic Acids Research, 40, D420-D427.

Gražulis, S., Merkys, A., Vaitkus, A. and Okulič-Kazarinas, M., (2015). "Computing stoichiometric molecular composition from crystal structures." Journal of Applied Crystallography, 48, 85-91.

Harlow, G. E., (1982). "The anorthoclase structures: the effects of temperature and composition." American Mineralogist, 67, 975-996. Available at: http://rruff.info/ doclib/am/vol67/AM67_975.pdf.

Hendricks, S. B. and Jefferson, M. E., (1939). "Polymorphism of the micas with optical measurements." The American Mineralogist, 24(12), 729-771.

Herrmann, W. and Berry, R. F., (2002). "MINSQ - a least squares spreadsheet method for calculating mineral proportions from whole rock major element analyses." Geochemistry: Exploration, Environment, Analysis, 2(4), 361-368.

Hilsdorf, H., Kropp, J. and Koch, H., (1978). "The effects of nuclear radiation on the mechanical properties of concrete." ACI SP 55, 223-251.

Hlavay, J., Jonas, K., Elek, S. and Inczedy, J., (1978). "Characterization of the particle size and the crystallinity of certain minerals by IR spectrophotometry and other instrumental methods - II. Investigations on Quartz and Feldspar." Clays and Clay Minerals, 26(2), 139-143.

Hobbs, L. W. and Pascucci, M. R., (1980). "Radiolysis and defect structure in electron-irradiated $\alpha$-quartz." Journal de physique, 7(41), 237-242.

Hollocher, K., (2009). "Calculation of a CIPW norm from a bulk chemical analysis." Geology Department, Union College, Schenectady, NY 12308, U.S.A. Available at: https://web.archive.org/web/20130403085053/http:// minerva.union.edu/hollochk/c_petrology/norms.htm.

Igarashi, G., Maruyama, I., Nishioka, Y. and Yoshida, H., (2015). "Influence of mineral composition of siliceous rock on its volume change." Construction and Building Materials. 94, 701-709.

Jercher, M., Pring, A., Jones, P. G. and Raven, M. D.,
(1998). "Rietveld X-ray diffraction and X-ray fluorescence analysis of Australian aboriginal ochres." Archaeometry, 40(2), 383-401.

Kaufhold, S., Hein, M., Dohrmann, R. and Ufer, K., (2012). "Quantification of the mineralogical composition of clays using FTIR spectroscopy." Vibrational Spectroscopy, 59, 29-39.

Kim, H. N., Kim, J. W., Kim, M. S., Lee, B. H. and Kim, J. C., (2019). "Effects of ball size on the grinding behavior of talc using a high-energy ball mill." Minerals, 9(11), 668.

Kleeberg, R., Monecke, T. and Hillier, S., (2008). "Preferred orientation of mineral grains in sample mounts for quantitative XRD measurements: How random are powder samples?" Clays and Clay Minerals, 56(4), 404-415.

Larrea, M. L., Martig, S. R., Castro, S. M., Aliani, P. A. and Bjerg, E. A., (n.d.). "Rock.AR - A point counting application for petrographic thin sections." Available at: http://cs.uns.edu.ar/ mll/web/files/papers/SCCG2010-rock-ar-martin-larrea.pdf

Le Pape, Y., Alsaid, M. H. F. and Giorla, A. B., (2018). "Rock-forming minerals radiation-induced volumetric expansion - Revisiting literature data." Journal of Advanced Concrete Technology, 16(5), 191-209.

Le Pape, Y., Sanahuja, J. and Alsaid, M. H. F., (2020). "Irradiation-induced damage in concrete-forming aggregates: revisiting literature data through micromechanics." Materials and Structures, 53, 62.

Levien, L., Prewitt, C. T. and Weidner, D. J., (1980). "Structure and elastic properties of quartz at pressure." American Mineralogist, 65(9-10), 920-930. Available at: http://rruff.info/doclib/am/vol65/AM65_920.pdf.

Livingood, P. C. and Cordell, A. S., (2009). "Point/counter point: the accuracy and feasibility of digital image techniques in the analysis of ceramic thin sections." Journal of Archaeological Science, 36(3), 867-872.

Lovas, G. Y. A. L. and Buda, G., (2004). "Efficiency of rietveld-based XPD quantification of mineral abundance in granitic rocks, a case study." Acta Mineralogica Petrographica, 45(1), 49-53.

Luu, V. N., Murakami, K., Samouh, H., Maruyama, I., Suzuki, K., Prak Tom, P., Chen, L., Kano, S., Yang, H., Abe, H. and Suzuki, M., (2020). "Swelling of alpha-quartz induced by $\mathrm{MeV}$ ions irradiation: Critical dose and swelling mechanism." Journal of Nuclear Materials, 539, 152266.

Marinoni, N. and Broekmans, M. A. T. M., (2013). "Microstructure of selected aggregate quartz by XRD, and a critical review of the crystallinity index." Cement and Concrete Research, 54, 215-225.

Maruyama, I., Haba, K., Sato, O., Ishikawa, S., Kontani, O. and Takizawa, M., (2016). "A numerical model for concrete strength change under neutron and gamma-ray irradiation." Journal of Advanced Concrete Technology, 14(4), 144-162.

Maruyama, I., Kontani, O., Takizawa, M., Sawada, S., 
Ishikawa, S., Yasukouchi, J., Sato, O., Etoh, J. and Igari, T., (2017). "Development of soundness assessment procedure for concrete members affected by neutron and gamma-ray irradiation." Journal of Advanced Concrete Technology, 15(9), 440-523.

Maruyama, I. and Muto, S., (2016). "Change in relative density of natural rock minerals due to electron irradiation." Journal of Advanced Concrete Technology, 14(11), 706-716.

Merkys, A., Vaitkus, A., Butkus, J., Okulič-Kazarinas, M., Kairys, V. and Gražulis, S., (2016). "COD::CIF::Parser: an error-correcting CIF parser for the Perl language." Journal of Applied Crystallography, 49.

Naus, D. J., (2012). “4.13 - Concrete.” Comprehensive Nuclear Materials, 4, 407-431.

O'Connor, B. H. and Chang, W.-J, (1986). "The amorphous character and particle size distributions of powders produced with the micronizing mill for quantitative x-ray powder diffractometry." X-Ray Spectrometry, 15(4), 267-270.

Omotoso, O., McCarty, D. K., Hillier, S. and Kleeberg, R., (2006). "Some successful approaches to quantitative mineral analysis as revealed by the 3 rd reynolds cup contest." Clays and Clay Minerals, 54(6), 748-760.

Pabst, A., (1952). "The metamict state." American Mineralogist, 37(3-4), 137-157.

Philippo, S., Naud, J. and Verkaren, J., (1997). "Geochemical evaluation of the Lueshe niobium deposit (Zaire) by Rietveld quantitative X-ray diffraction." Applied Geochemistry, 12(2), 175-180.

Poole, A. B. and Sims, I., (2016). "Concrete petrography." 2nd edi. London: CRC press.

Primak, W., Fuchs, L. H. and Day, P., (1955). "Effects of nuclear reactor exposure on some properties of vitreous silica and quartz." Journal of the American Ceramic Society, 38(4), 135-139.

Quirós, M., Gražulis, S., Girdzijauskaite, S., Merkys, A. and Vaitkus, A., (2018). "Using SMILES strings for the description of chemical connectivity in the Crystallography Open Database." Journal of
Cheminformatics, 10(23).

Ronov, A. B. and Yaroshevsky, A. A., (1966). "Chemical composition of the earth's crust." Geophysical Monograph Series, 13, 37-57.

Rosseel, T. M., Maruyama, I., Le Pape, Y., Kontani, O., Giorla, A. B., Remec, I., Wall, J. J., Sircar, M., Andrade, C. and Ordonez, M., (2016). "Review of the current state of knowledge on the effects of radiation on concrete." Journal of Advanced Concrete Technology, 14(7), 368-383.

Sasano, H., Maruyama, I., Sawada, S., Ohkubo, T., Murakami, K. and Suzuki, K., (2020). "Meso-scale modelling of the mechanical properties of concrete affected by radiation-induced aggregate expansion." Journal of Advanced Concrete Technology, 18(10), 648-677.

Scrivener, K., Snellings, R. and Lothenbach, B., (2016). "A practical guide to microstructural analysis of cementitious materials." CRC press.

Snellings, R., Machiels, L., Mertens, G. and Elsen, J., (2010). "Rietveld refinement strategy for quantitative phase analysis of partially amorphous zeolitized tuffaceous rocks." Geologica Belgica, 13(3), 183-196.

Takahashi, H., (1957). "Effect of dry grinding on kaolin minerals." Clays and Clay Minerals, 6(1), 279-291.

Toby, B. H., (2006). "R factors in Rietveld analysis: How good is good enough?” Powder Diffraction, 21(01), 67-70.

Ufer, K., Stanjek, H., Roth, G., Dohrmann, R., Kleeberg, R. and Kaufhold, S., (2008). "Quantitative phase analysis of bentonites by the rietveld method." Clays and Clay Minerals, 56(2), 272-282.

Vaitkus, A., Merkys, A. and Gražulis, S., (2021). "Validation of the crystallography open database using the crystallographic information framework." Journal of Applied Crystallography, 54(2), 661-672.

Vrsweueruanhnowic, K. and Kielhorn, H.-M., (1983). "Al, Si distribution in a ternary (Ba, K, Na)-feldspar as determined by structure refinement." American Mineralogist, 68, 122-124. 